\title{
The problem with UCAS personal statements
}

Link to publication record in Manchester Research Explorer

\section{Citation for published version (APA):}

Jones, S. (2012). The problem with UCAS personal statements. SecEd (Secondary Education), (321), 12.

\section{Published in:}

SecEd (Secondary Education)

\section{Citing this paper}

Please note that where the full-text provided on Manchester Research Explorer is the Author Accepted Manuscript or Proof version this may differ from the final Published version. If citing, it is advised that you check and use the publisher's definitive version.

\section{General rights}

Copyright and moral rights for the publications made accessible in the Research Explorer are retained by the authors and/or other copyright owners and it is a condition of accessing publications that users recognise and abide by the legal requirements associated with these rights.

\section{Takedown policy}

If you believe that this document breaches copyright please refer to the University of Manchester's Takedown Procedures [http://man.ac.uk/04Y6Bo] or contact uml.scholarlycommunications@manchester.ac.uk providing relevant details, so we can investigate your claim.

\section{OPEN ACCESS}




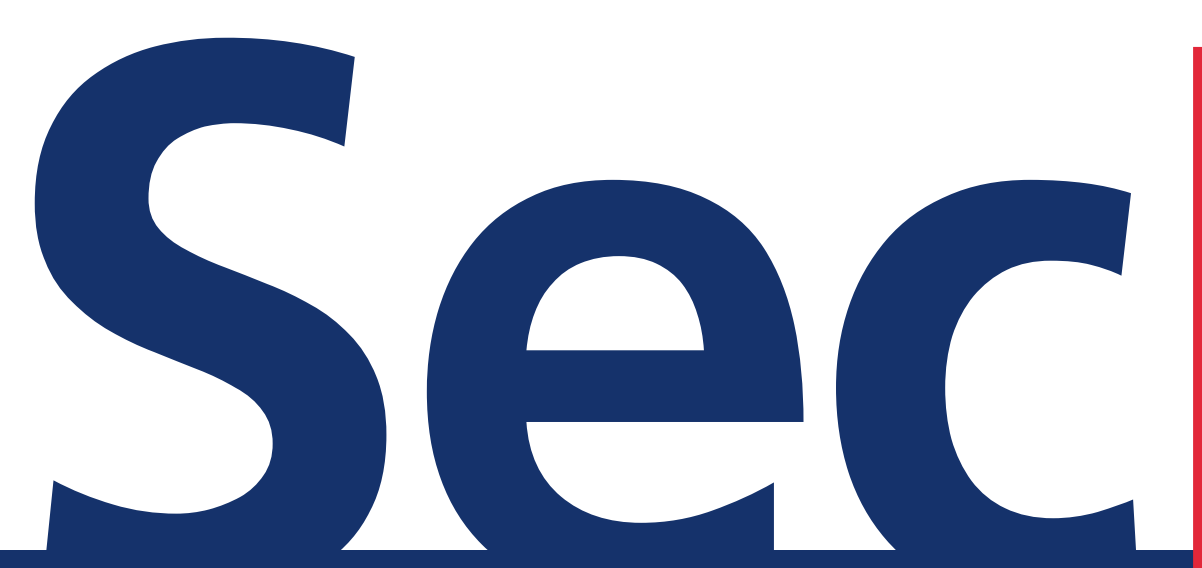

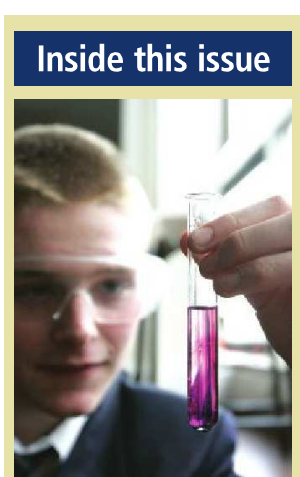

Attitudes

to STEM

Research shows that pupils attitudes to STEM learning and careers change as they move from key stage 2 to 3 . We

look at why this is and what it means for schools

Pages 8 and 9

Applying to HE

The UCAS personal statement is meant to level the university playing field for students, regardless of their background. We look at new research showing that it may actually be part of the problem

Page 12

Governor top tips A National Leader of

Governance gives her 12 top tips for effective governing Page 13

SecEdonline For regular news updates and our full editorial archive, visit wnw.sec-ed.co.uk. You can also sign up to receive SecEddigital, a free regular e-bulletin which includes a virtual edition of SecEd by emailing editor@sec-ed.co.uk. Follow us on Twitter at wnw. twitter.com/SecEd_Education

MPs call for lead autism
teacher in every school Cross-party report highlights importance of specialist training

\section{By Pete Henshaw}

Every school should have a lead teacher for autism, MPs have said after hearing about a lack of specialist support for students with A report

A report by the All-Party Parliamentary Group on Autism (APPG) says that teachers are not able to support children with the able to support child
condition effectively.

MPs also conclude that the lack of specialist support leads many parents to feel that schools simply do not understand autism.

The report, The Right Start, is based on research conducted earlie this year, including a public survey of 1,000 people and two hearings, at
which MPs quizzed teachers, SEN experts and young people.

Autism is a lifelong disability that affects the way a perso communicates with and relates to other people. Around one in 100 people has autism, including 88,000 school-aged children in England statements.

The MPs' survey found that 89 per cent of parents or teachers of children with Asperger syndrome or high-functioning autism said that teaching staff do not get enough training to teach and support children with autism effectively. During the hearings, Josie Ryan, a young person with autism and young patron of the charity Ambitiou experience of going to a mainstream school: "I really didn't enjoy it, because the lack of understanding from teachers is quite ridiculous, actually. Most teachers don't even know (autism) exists. They didn' have any idea what it was."
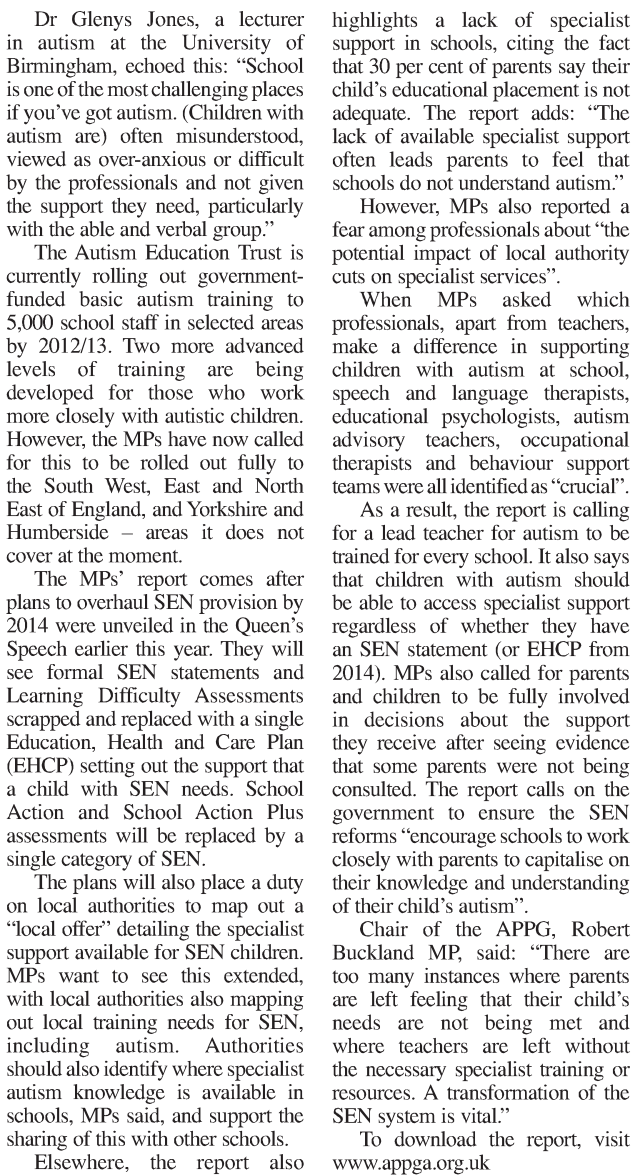

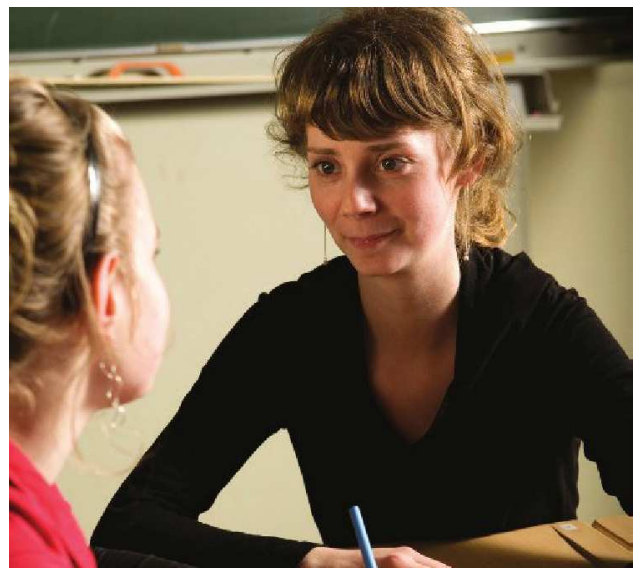

The 3,000 hidden deaf-blind children

Concern has been raised at evidence of a significant underidentification of deaf-blind children in our schools.

In a recent survey of 56 local athorities, just 549 deaf-blind the Pupil were identified, while Census records a total of 935 deaf-blind children in England.

However, a report from deafblind charity Sense, says that there are an estimated 4,000 such children in England, meaning that as many as 3,000 are missing out

on vital support. The report,

Supporting

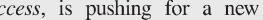
duty for education, health and care agencies to identify all deafblind children in their area. It states: "The duty would identify the needs of deaf-blind children, which will inform service planning, commissioning and the provision of early intervention and support at key stages of need." children to be identified earlier and also included in the government's pilots of SEN reforms.

Download the report at Download the report at supporting_success_report
Set of three lesson observation DVDs

Created to reflect the requirements of the new Ofsted framework, published in January 2012

Made by Tony Thornley, ex-HMI and ASCL consultant; author of ASCL's SEF and self-assessment guidance.

For more information or to place an order go to www.ascl.org.uk/lessonobservations
To be used by schools for professional development related to teaching, learning and inspection. Each DVD will last around two hours and contain:

- Two observed lessons

- Examples of inspectors gathering first - Judence of learning and progress, teaching and behaviour in each lesson.

- Supporting lesson documentation which teacher might normally be provided to a lesson

observer. 


\section{SecEd Newly qualified struggling \\ To subscribe, call 01722716997 \\ Editor \\ Pete Henshaw
02075016771 \\ 02075016771 editor@sec-ed.co.uk \\ to find work in Scotland}

@pwhenshaw (Twitter)

Abdul Hayee

02075016767

Advertising/Sales Executive

Robbany Khan
02075016759

法.com

Circulation Director

Sally Boettcher

Managing Director

Matt Govett

Chief Executive Officer

Editorial Board

SecEd is advised by an editorial

advisory panel. Members include:

Belvoir High School, Leicestershire.

Mark Blois: partner, Browne

Jacobson (education law solicito

Hanham High School, South

The Royal High School, Edinbur

Mike Griffiths: headteacher,
Northampton School for Boys.

Hilary Moriarty: national director

Bearll Mortoo: s $^{\prime}$ Association.

Portororton

Jo Smith vice rinci Enniskille

Field School, Melton Mowbray

Tina Stockman: teacher, Harlaw

Academy, Aberdeen. Dr Bernard

Trafford: headteacher, The Royal

Tyne. Simon Viccars: headteach

land Sports College

UK Annual Rates:

Personal: $£ 54$

panies, etc) $£ 120$

European annual rates:

Personal: $f 92$

Institutional: $f 165$

Rest of world annual rates:

Personal: $f 113$

Institutional: $f 209$

Circulation department

01722716997
subscriptions@markallengroup.com

MA Education Ltd is part of the

il

AP

www.markallengroup com

SecEd is published by

MA Education Ltd

St Jude's Church, Dulwich Roa

02077385454

www.sec-ed.co.uk

() SecEd 2012. All rights reserved. No part of SecEd may be reproduced, stored in a retrieval system, or transmitted in any form by any means,
electronic, mechanical, photocopying, recording or otherwise without prior Written permission of Managing Director
The publisher accepts no responsibility for any views or opinions expressed in

MA Education Ltd is an independent publishing house which also produces Fundraising for Schools, Early Years Educator \& Primary Teacher Update.

ISSN 1479-7704

Printed by Pensord Press Ltd

\section{Crecycle}

\section{By Sam Phipps} \\ Teaching in Scotland is becoming an increasingly "casualised" after a survey by the Gener Teaching Council for Scotland (GTCS) showed only a quarter of found full-time permanent posts six to eight months after ending their \\ The figure of 24.9 per cent in those kind of positions was a rise on employment and there appears to be \\ Inspection results hit by tougher regime \\ more than a third of respondents contracts, up from 25.5 per cen unemployed accounted for 12 pe survey, down from 162 per cent. Anthony Finn, chief executive
of the GTCS, said. "These figures show an improving picture of the teachers. But there are clearly still difficulties. Too many talented way of knowing the employment tus of those who declined. \\ Larry Flanagan, general like the figures bottomed out in Only 22.7 per cent of new} the stability of the profession, and rising number of teachers taking young people. work, were causes for concern. A new pay deal last year halved pretax supply rates to about $£ 78$ a day. concern over the apparent growth in short-term and temporary contracts for teachers. While the creation of quality of those jobs must also be considered.

"The marked growth in the us local authorities is leading to the casualisation of the teaching
workforce and robbing schools and pupils of the vital stability that is needed to ensure a high-quality learning and teaching experience in all parts of our education system." Mike Russell said: "The mos the most claiming Jobseeker's Allowance, from April 2012, were lower than in the same month in 2011. This positive trend has emerged over the past 20 months and I am keen to

\section{Cut in secondary training places}

Education boards are working to
He added that Ofsted needed urgently to "recalibrate" its
judgement to prevent "a repeat of these fluctuation since the introduction of the new
framework in January, officia figures show.
They confirm that under new chief inspector Sir Michael Wilshaw's regime, schools arc finding it much harder to gain the op "outstanding" grade.
According to statistics from the schools' watchdog, of the England inspected between January and the end of March this judged "outstanding" for overall effectiveness, 50 per cent (979)
were judged "good", 34 per cent (658) were judged "satisfactory" and nine per cent (183) of schools were "inadequate".

academic year 2010/11 with the rents udged outstanding, 46 per cent ain a good or outstanding grade.

f the National Association of Head eachers, said a "dive into the ed that there was a lack "In the first month of the new were failed. In the third month, wis figure is just four per cent. This suggests either an attempt by inspection workforce which nly now becoming competent at applying the framework correctly,

"Ensolation for schools inspected in January, and for those leaders who

Brian Lightman, general secretary of the Association for he had concerns about further changes in inspections due to be mplemented in September and expected a system of support to be in place to help those schools
found to be in difficulty under the new arrangements.

"One of the big concerns has quality and apposistency in the teams which in some cases has led to inaccurate judgements," he said. "With yet more changes only a few months away, Ofsted must make sure all inspectors are
properly trained and understand properly trained and understand what is required. This is critical if with the profession."

\section{School heralds impact of computer gaming}

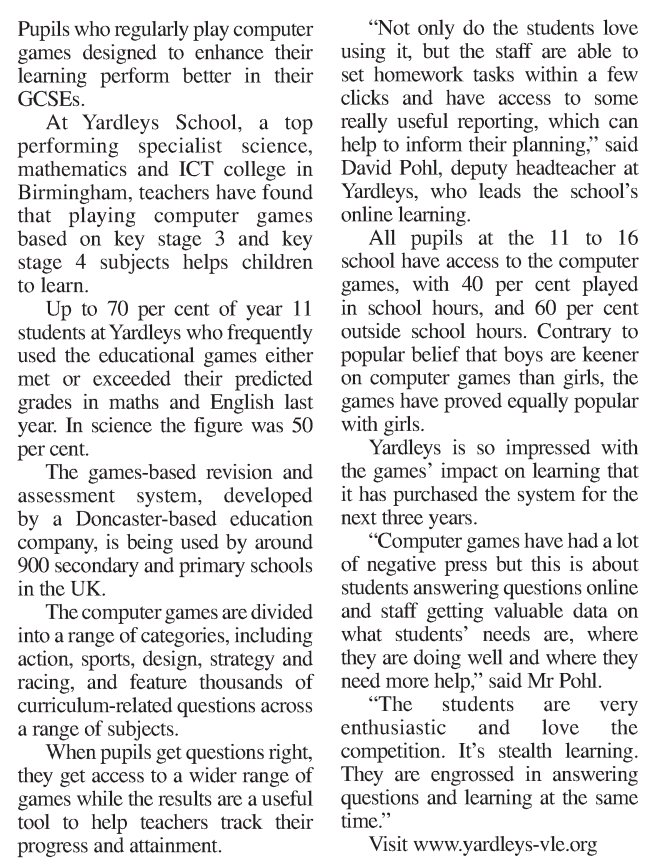

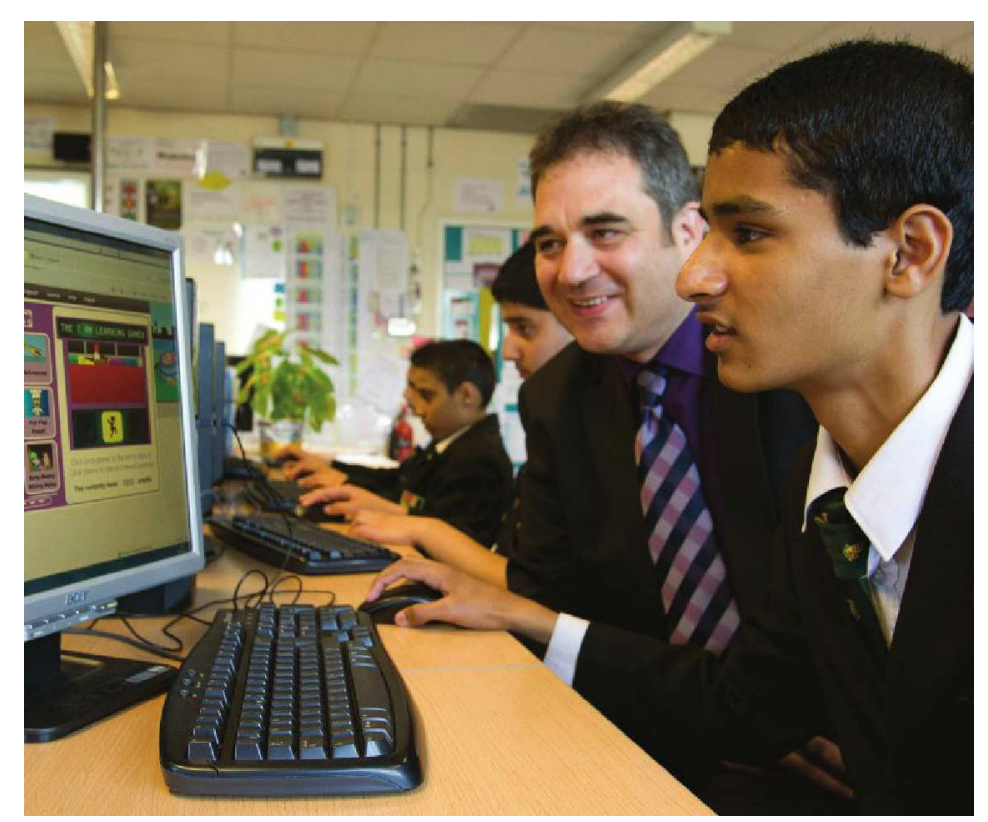

Playing to learn: Computer games helped Yardleys School students to improve results 


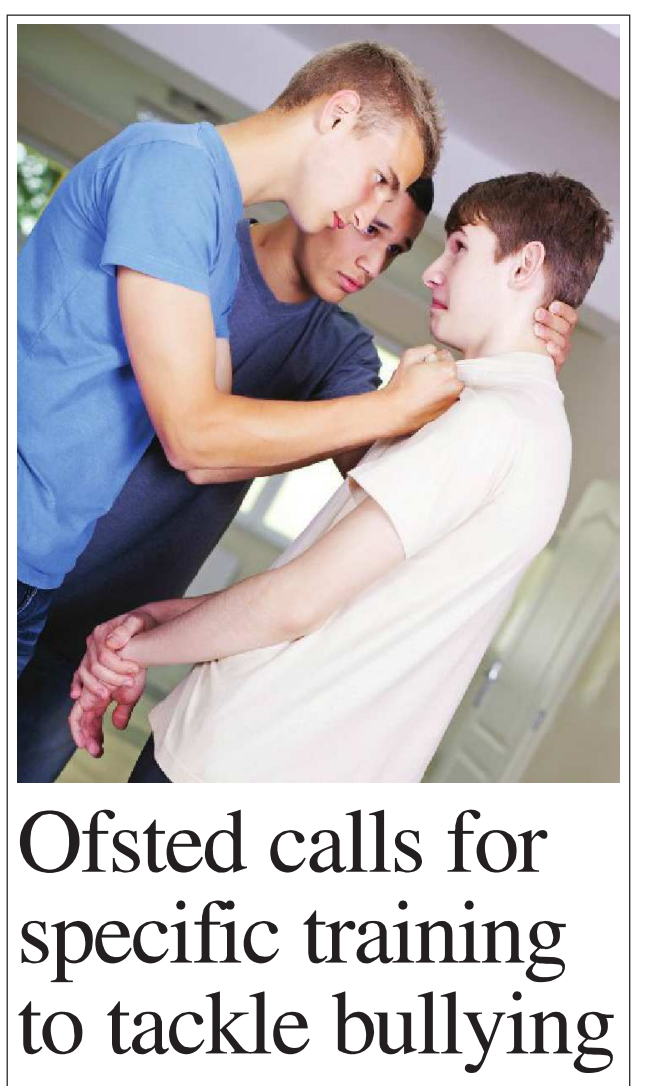

Teachers and school staff feel least confident when tackling prejudicerelated language, a report int The report by school
The in schools has shown. inspectorate calling for staff to receive more
specific training in order to help them tackle the varying kinds of bullying that take place in schools.
The report, entitled No Place for Bullying, is based on inspectors visits to 37 school, including 19 secondaries, late las year and Ofsted reported that a lot of anti-bullying training was too general and left school staff "not
feeling wholly confident" to tackle different kinds of incidents.

It states: "The training that the majority of schools had provided on bullying tended to be general and did not always focus on the different types of bullying that of these.

"At its best, training left staff very knowledgeable about the different forms of bullying that could be faced by pupils and different forms of discrimination." It also said that pupils in all of the schools visited could give language that they heard in school - related to perceived ability, race, religion, sexuality, appearance r family circumstances. "Homophobic language wa
frequently mentioned," it adds.
Dyslexic pupils hit by changes

\section{to exam support}

\section{By Dorothy Lepkowska \\ A leading dyslexia charity says that thousands of dyslexic students are changes to access arrangements for GCSEs and A levels. \\ In the past few years, high- performing pupils with dyslexia arrangements, such as being given extra time in which to complete examinations, taken away following criticisms from some that this \\ Dyslexia Action is involved in an on-going discussion with the Joint Council for Qualifications (JCQ) to have the access arrangements
reinstated, claiming that the reinstated, claiming that the
condition poses greater problems for young people than just with reading. These include problems with organisation, mathematics and} memory which can result in slow reading, writing and information processing.

Although dyslexia does not affect at a serious disadvantage in exams, which test reading, comprehension, within a set period of time.

still need exam access arrangements to ensure they are not disadvantaged compared to their peers. It is the individual's capability that needs to be the focus."

$\mathrm{He}$ added that a lack of understanding of the challenges faced by dyslexics left them "under picion of cheating". Michael Turner, the JCQ's director, said: "We agree that candidates who meet the criteria for access arrangements should not be labelled as having an unfair advantage.

"Access arrangements include variety of options including coloured overlays, supervised rest breaks, use of word-processors and, in extreme cases, extra-time, reader and scribes. In developing these wide wide range of key stakeholders to we the to all candied.

"To achieve a level playing field, it is essential that extra time is only provided to those who meet strict criteria. As such, it cannot be awarded to candidates with a high IQ and who have processing speed well within the national average." intelligence it can put an individual

\begin{abstract}
Kevin Geeson, CEO of
Dyslexia Action, said: "Dyslexia is a recognised disability under the Equalities Act 2010. Therefore, examination access arrangements, ensure a level playing field. "It is wrong to undermine the achievements of a young dyslexic person by saying their extra time gives them an advantage over other dyslexic student has had to work twice or 10 times harder to be able to demonstrate their knowledge of the subject being examined, co

their non-dyslexic peers." Mr Geeson said there remained "a lot of confusion" around
the access arrangements for xaminations.

$\mathrm{He}$ continued: "Our main concern is that the JCQ's regulations will only allow for students who have considerable disability and adjustments will only be made average equivalent

"Dyslexia affects different individuals differently and severity can vary greatly. We are therefore worricd that this could pose considerable threat to those students who are above average in ability but
\end{abstract}

\section{Schools given $£ 17 \mathrm{~m}$ to build links to developing world}

The government is giving $£ 17$ million to help support links between UK schools and 29
developing countries around the developing countries around the
world over the next three years. The funding has been given to the on-going Connecting Classrooms programme, which is supports UK school links and partnerships with more than 50 countries worldwide.

The new money will allow 1,800 schools to benefit from a full programme of support, will be able to collaborate with overseas partners online via webconferencing, discussion forums and mobile phone apps.

Schools will be encouraged to make creative use of technology, including joint assemblies with
children in other countries via web-conferencing and the use of interaction between classrooms

a dedicated website to help find and open up new understanding of suitable links, keep in touch and develop their partnerships. Teacher will also be urged to take part in online forums to collaborate and hare expertise.

International developmen secretary, Andrew Mitchell, said: "This new programme will allow more children growing up in the KK to learn about the world around them, about the facts of poverty in developing countries. I urge all schools to consider how they can use this Gove, added: "International links pupils. This progreachers and geographical boundaries to spark societies, languages
around the world"

Elsewhere, courses in school leadership will help more than 3,200 heads overseas to improve their school management skills, while teachers in the UK will expertise with peers in developing countries, through a mentoring The Connecting Classrooms programme will also allow more than 15,000 teachers to complete in global citizenship, ICT and English language for international exchange. Visit http://schoolsonline. britishcouncil.org/programmesand-funding/connecting-
Education secretary, Michael between schools can be hugely be able to share their leadership

\section{Public reveals fears over impact of regional pay}

Two-thirds of voters believe that move to regional pay will make harder for schools in some areas

The government wants to move o regional pay - whereby public sector pay is linked to the local
private sector rather than a national pay framework.

The move could mean that as many as six million public sector
workers see their pay reduced.

The study, carried out by polling
Thers see their pay reduced. company Survation on behalf of the TUC, also found that 75 per cent of
the 1,000 adults polled also want to see an independent economic
impact assessment on the possible impact assessment on the possible
consequences of regional pay on local communities.

The independent pay review bodies for the various public sector professions, including the School Teachers' Review Body, have
been asked by chancellor George Osborne to look into the idea of regional pay and are due to report later this year.

In his Budget speech earlier this year, Mr Osborne said: "London weighting already exists across the
public sector. So we should what we can do to make our public our private sector to grow and create jobs in all parts of the country."

If approved, hit hardest by the move would be teachers in Wales, which has an 18 per cent pay gap

Elsewhere, the pay gap in Yorkshire/Humber and also
Scotland is 13.4 per cent. The East England stands at 13 per cent, Northern Ireland at 12.3 per cent The South East by comparison has just a 0.5 per cent gap an

The TUC has repeatedly callo on ministers to shelve the plans and commenting on the study, general 'Nury' Brendan Barber, said: 'Nunses and teachers' pay should be set by the job they are doing rather than how wealthy their local "Paying someone more to save lives or teach a child in a rich area is not only deeply unfair, it also makes no sense at all"

Christine Blower, general
Teachers, added: "Only (education secretary) Michael Gove has expressed any support for local teaching. Submissions to the School Teachers' Review Body show that everyone else consulted local authorities, headteacher associations, governor association oppose the idea.

"This policy would reduce teacher mobility, create shortages in areas of lower pay, hit recruitmen and retention, and create needles extra expense and bureaucracy fo

\section{In brief}

Global forum

Almost 700 students will com together this week to discus in the dou food security in the developing world. The 6h-lom his thar's Genal Student Forr th 26). The theme of this year's meeting is "Hungry for Justice". Since the Forum's inception in 2005 , more than 4,000 6th-formers have attended the annual meetings across the UK before returning to their schoo 350,000 students. Visit: 


\section{More than half of new teachers} to be trained on-the-job by 2015

\section{By Pete Henshaw}

More than half of all teache training places will be delivered
by schools by the end of this by schools by the end of this
Parliament, the education secretary has saic.

Michael Gove has also unveile plans to give trainee teachers
financial incentives of up to $£ 5,000$ to work in challenging schools. In a speech to delegates the National College for School Leadership annual conference last 15,000 training places could be based in schools by the time of the next General Election.

His plans include a dramatic Department for Edhools Direct, programme which invites Teaching Schools to bid for teacher training places.
It is expected that there will be more than 900 training place via Schools Direct in September and Mr Gove is now ope
scheme up to all schools.

He said: "Those participating will be able to recruit their own trainees and develop their own training programme in partnership with a university. In return for will be expected to find a job for the trainee once they finish their

"Schools won't have to be part of a Teaching School alliance to get involved but we envisage that most
will - because the advantages of

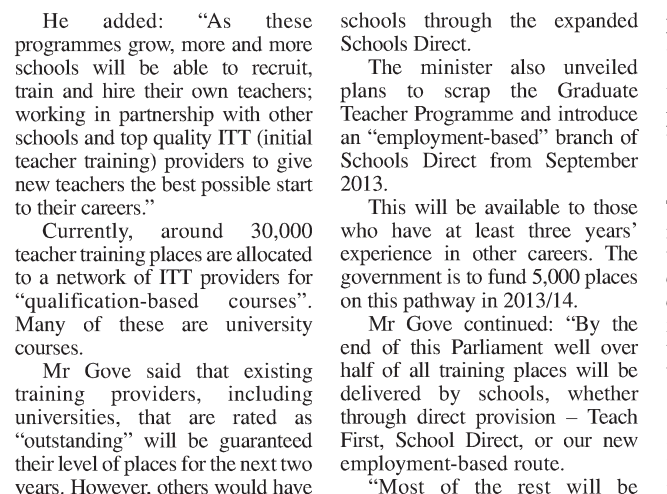

providers rated outstanding," he added.

Teachers and heads this week warned that a combination of
practical and theoretical training was essential.

Christine Blower, general secretary of the National Union of Teachers, said: "Trainee teachers not only need practical training but the time and space to develop and exchange ideas on best practice in education. It is therefore vitally important that graduates continue to have part of their

Brian Lightman, general School and College Leaders, said: "Practical, hands-on experience we welcome the commitment to
building on existing best practice in school-based training. "An understanding of subject methodology needs to be a central component. Teaching is a science as well as an art and there is an about young people which all trainees need to have.

"All good teacher training will be a blend of both the practical and Elsewhere, Mr Gove also said that if a Schools Direct trainee spends "the majority of their
training in a challenging school" then they will receive an extra 25 per cent in bursary payments. Those starting in September
Then years. However, others would have will get up to $£ 5,000$ extra.

\section{Wilshaw: 'Radical solutions' to help disadvantaged}
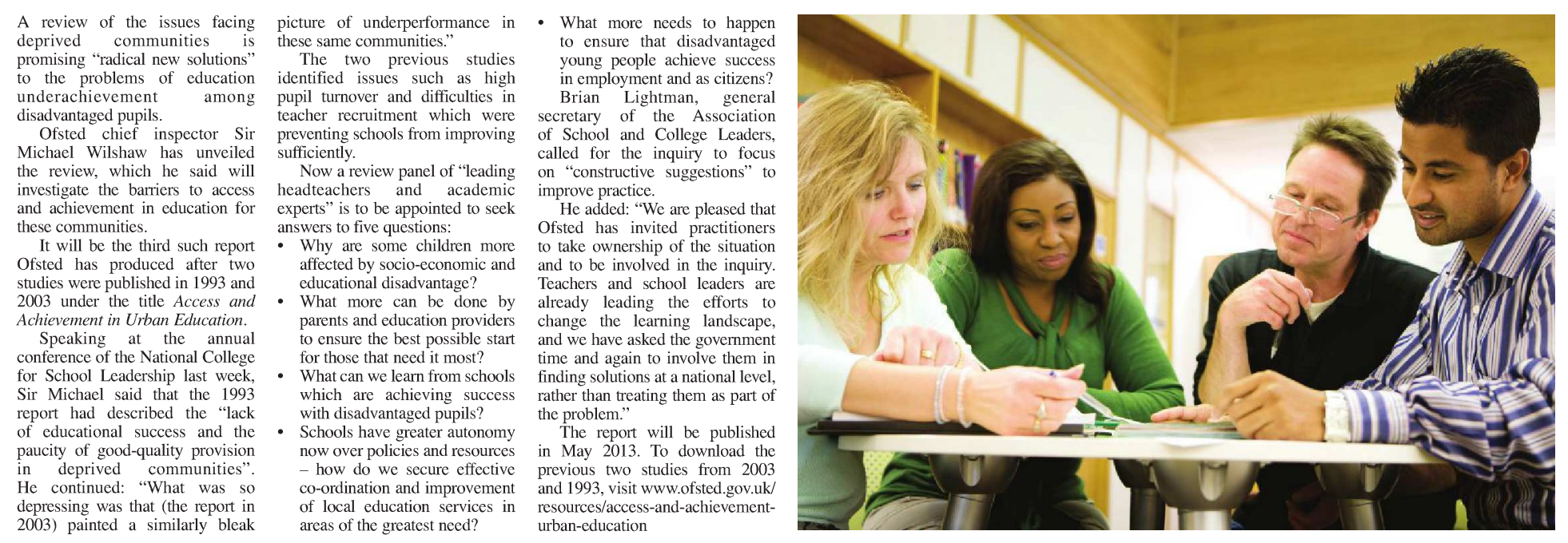

Estyn praises schools for

their perfo now benchmarking schools and sharing good practice more often, according

Estyn says schools are increasingly making good use of performance and identify areas for improvement.

Introduced by the Wels information on a school's results against local and national
performance; the difference in performance between girls and who receive free school meals and those who do not; and comparisons with performance of meal benchmarks.

In a new report on schools' use inspector of education and training in Wales, said: "Historically, there how schools and local authorities performance to identify areas from improvement. Now with the introduction of the All-Wales Core Data Sets, every school in
Wales is able to identify higherperforming similar schools so th complement the core data an explain their value.

However, the report also found that one-in-five schools is enough to help them identify what they need to improve. Inspectors use data to justify what they do currently, rather than challenge

\section{Passion is the secret to Oxbridge admissions}

Students aspiring to Oxbridge should develop their intellectual
abilities around subjects they are abilities around subjects they are
passionate about - even if they are perceived to be common and unimpressive.

The advice comes from an academic who has spent five year training students for

Dr Christopher See, wh eaches in the Faculty of Medicin at Manchester University, says
that displaying a genuine interest that displaying a genuine interest
in a subject is better than doing something for
admissions form.
For example, he argues that a can be developed into academic study looking at the socio-cultural behaviour in online groups, while budding stand-up comedians might look at the linguistics and origin of humour or the neurological mechanisms of laughter originality, commitment and curiosity of this kind will impress Oxbridge admissions tutors much more than a faked

traditional subjects.
Dr Sec, a Cambridge graduate himself, explained: "People excel in what they are passionate about. Don't do things for the sake of an personal growth.

"Pupils of this age are often very
"Panal growth. poor actors and are easily found-out if they pretend to be interested in something they are not.

"The Oxbridge application is and enthusiasm. I help pupils take seed of interest and develop it in wefore. It's this love of what they do that will sustain them when they re overworked and pushed to their limits."
Dr See, who is also a medic University Hospital Aintree, is How to Get Into Oxbridge, which How to Get Into Oxbridge,
was published last month. $\mathrm{He}$ also suggests regular pressure that candidates often trategy" for family, friends and eachers, with weekly parentstudent meetings to avoid regular interrogation from parents, and codes of behaviour that guarantec

glowing teacher references. How to Get into Oxbrid
(Kogan Page) costs $£ 14.99$.

\section{Pupil switch-off plea}

Pupils are so used to accessing radio, the SmartPhone, the TV, information in speedy, bite-sized and any other distractions, and $\begin{array}{ll}\text { are missing out on studying more } & \text { ray from cover to cover, but I'm }\end{array}$ are missing out on studying mor Tha's executive of the Girls' Day Schoo Trust (GDST), who has warned that the internet is "infantilising" youngsters' learning. Speaking a last week, Helen Fraser sai that learning should sometime be like "a slow casserole, with knowledge stewing in our minds to form a richer, deeper flavour". in the importance for our students in the importance for our students not really bothered whether it's paper or an e-book.

"The important thing is that it's read from start to finish following an author's train of thought, through perhaps situations, from first principles through to their conclusion. It's only by learning deeply about and around a subject that you can

The GDST is a charity that runs a network of 26 schools in England
and Wales. 


\section{arte minds \\ Celebrating \\ Cultural \\ Diversity \\ in the United Kingdom}

\section{$£ 1,000$ s IN PRIZES TO BE WON}

The competition

The NASUWT annual ort \& mind, Competition aims to promote and celebrate cultural diversity.

The Competition is open to children and young people from primary, secondary and special schools across the UK.

- Using artwork and creative writing, pupils explore what diversity, equality and identity them and how this is reflected in their lives, families, schools and communities.

- Teachers can incorporate the competition into lessons on various subjects, including history, humanities, literacy, art and citizenship, and school projects.

There is an art category for all forms of art, including photography, digital artwork and collages.

- The creative writing category is for stories, poetry and lyrics, including the Anne Frank Poetry Award for poems inspired by the life and writing of Anne Frank.

Awards ceremony and prizes

ceremony on 9 October 2012 and will include:

- $\quad \varepsilon 1,000$ for the overall winning school

- $£ 350$ for all winning schools:

- gift vouchers worth up to $£ 100$ for winning pupils;

- overnight accommodation at a deluxe London hotel and appropriate travel and subsistence expenses for winning pupils, their parent/guardian and a teacher

- a visit to a top London attraction.

CLOSING DATE: 2 JULY 2012

To obtain an application form and more details, go to: www.nasuwt.org.uk/ArtsandMinds

Telephone: 01214536150

Sponsored by
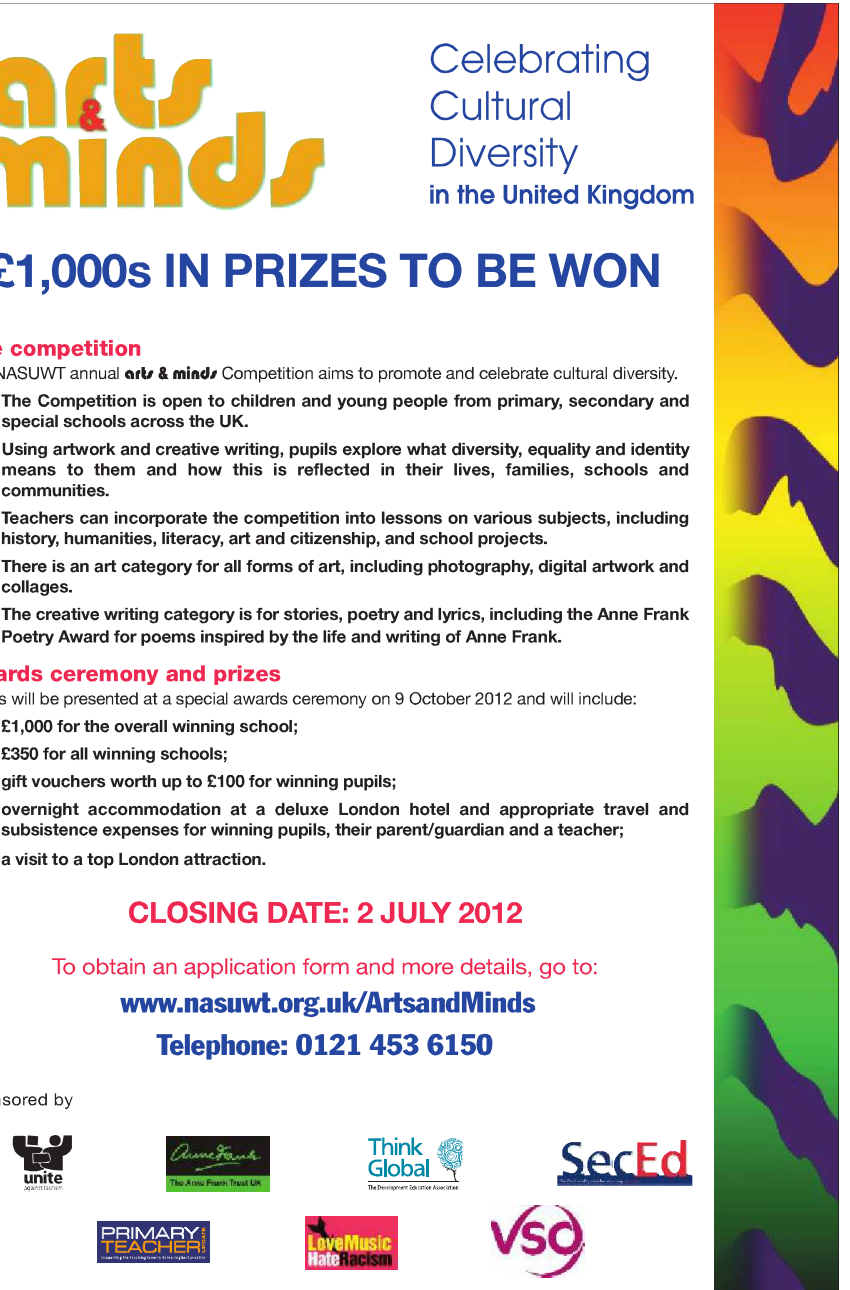

\section{Inspiring spaces} for young minds
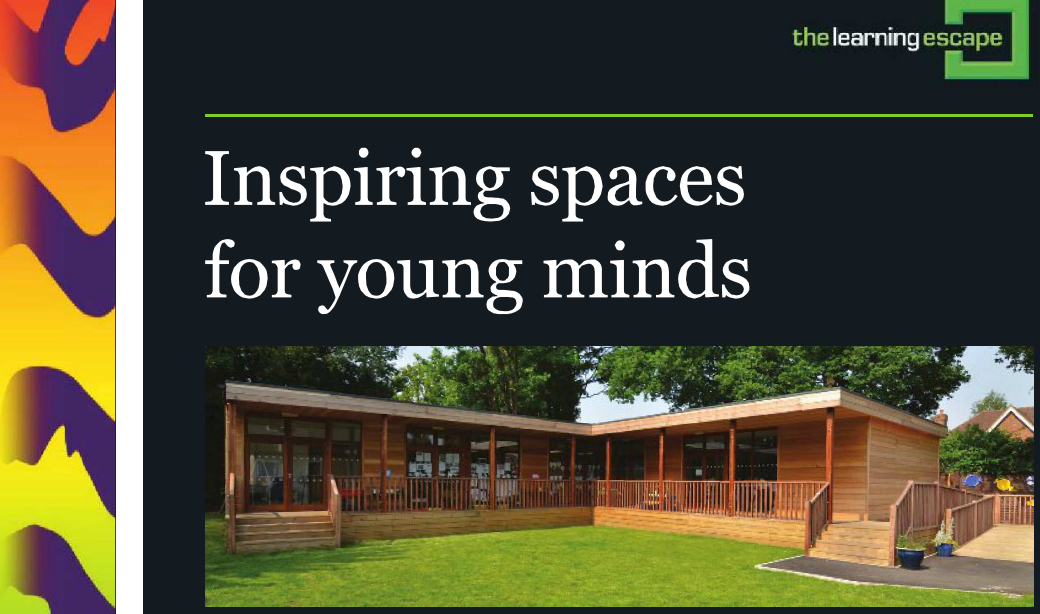

In a place where young minds are moulded it's important to have an environment that is inspiring and motivating. At The Learning Escape we design innovative buildings that encourage outdoor learning and educational play to help re-connect students to nature.

Flexible buildings designed for your space can grow as you do, with features like sun pipes, living sedum roofs, solar water systems as well as $\Lambda \Lambda$ rated cooling \& heating. Our eco-friendly buildings help staff promote environmental citizenship amongst pupils and the wider community. We build exactly what you need using sustainable red cedar, be it an eco-classroom, staff room, school hall or library and can include decking and canopy to facilitate outdoor activities whatever the weather.
We talk to your staff and pupils to find out their ideas and needs, then create a stunning and sustainable building that fits into your space and budget. Our educational specialist team has years of experience and will design a stimulating environment that can be used for learning alongside recreational and activities.

The Learning Escape provides a full service. We know how busy the school day can be and that's why we handle all the administration, planning permissions and safety compliance. We want to make sure that the build disrupts you as little as possible so we work hard to keep within your timetables and budget.

For a free survey call us on 08009177726

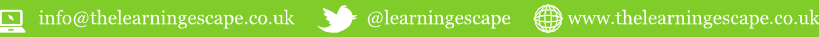

Clobal Online Learning Platform Class Discussions Assignments Educational Videos Secure File Storage Monitored Email Blogs
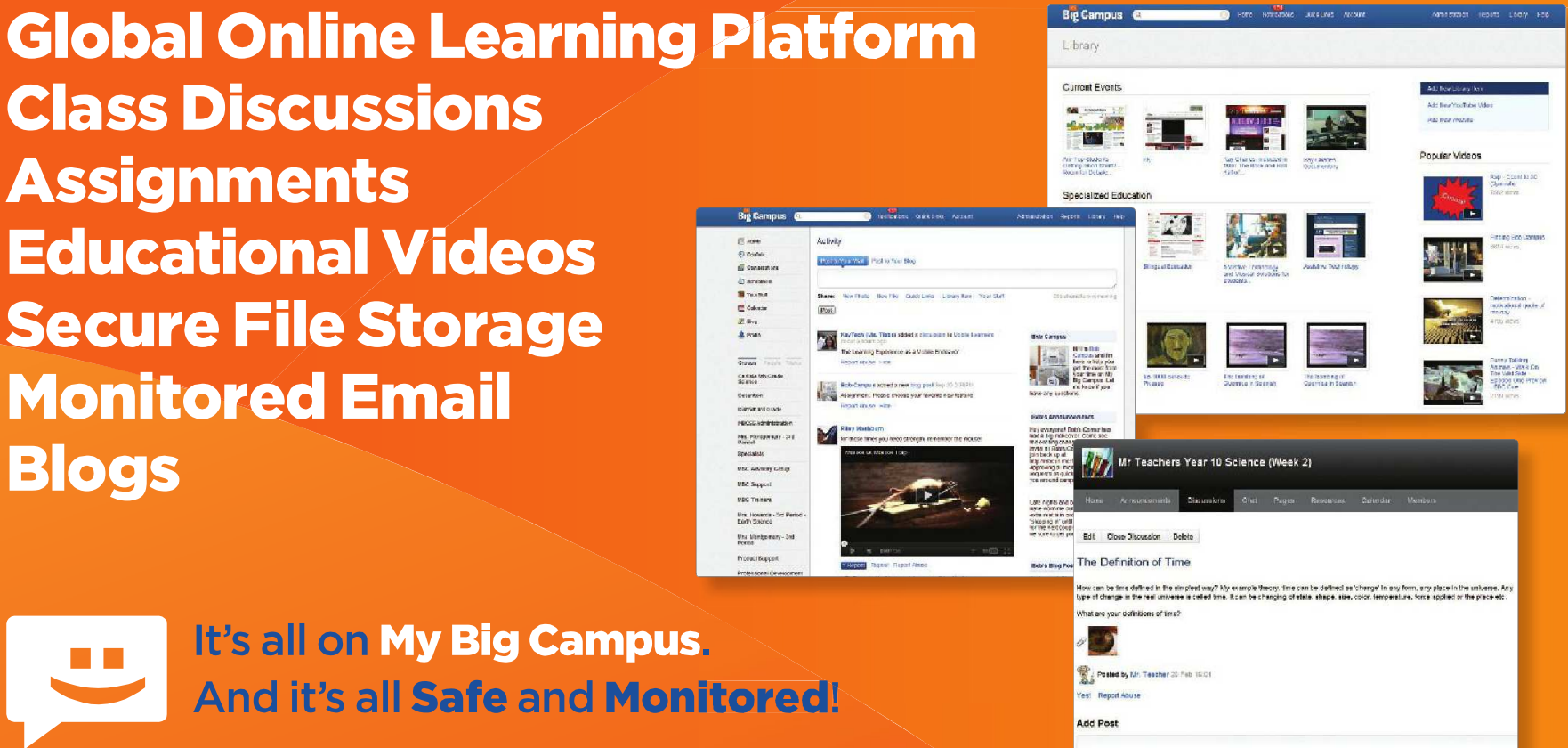

\section{Bigg Campus}

Join Bob Campus and more than 750,000 users today!

Just go to www.mybigcampus.co.uk to find out more or contact us on 01277240630 
SecEd: On Your Side

\section{A shameful tale that eptiomises the cuts}

WHILE IT is a minor scene

\section{in the grand tragedy of}

government cuts and their

impact on vital community

services, the following story

somehow seems to sum up the

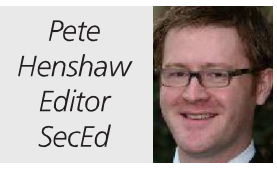

injustice of our current era of austerity.

At the end of last month, council workers - backed up by police officers - entered a local library at 3 am in the

morning, emptied it of books and shut it down.

The ominously Orwellian incident threatens to bring an end to a long-standing campaign to save the facility - a campaign led and heavily supported by the local community.

This library was opened by Mark Twain 112 years ago,

but this did not prevent it being stripped of books, furniture murals painted more than 80 years ago, and even an historic plaque marking its opening in 1900 by the American author.

The campaign to save the Kensal Rise library in Brent,

north London, has been run by the local community

for some time with some notable authors lending their

impassioned support (www savekensalriselibrary org).

The Labour-run administration in Brent had approved its

closure alongside that of five other libraries in the borough

back in April last year. This is despite the fact that more than

80 per cent of people who responded to a council survey

opposed the closures.

The Kensal Rise campaigners lost a challenge in the High Court and Supreme Court earlier this year. Since then they have maintained a watch on the library in a bid to block any clearance, but the night-time raid caught them unawares.

The library building belongs to All Souls College in

Oxford, which had gifted it to the people of Brent in 1900 on the condition it be used as a library. The Guardian reported that in an email sent to one campaigner, an Al Souls' representative described the clearance as "distressing" and said that they had told Brent that they would have been happy for the library to remain open with the help of the local community.

The campaigners still have the hope of engaging with All Souls, but Brent Council must be held to account for the way it has ignored the good will and the wishes of a community under its care. Was this not an ideal moment to prove that the Big Society can work?

So many decisions are being taken at the moment in which elected representatives use the austerity regime as justification for rail-roading local people and ignoring their views. It seems as if once politicians get elected, whether local or national, they seem to forget their ultimate responsibility and deem that they have the power to decide what is best for communities without listening to those same communities.

The books were not quite taken out into the night and burned (they have been redistributed to other libraries and outreach services around the borough), yet the nature of this whole affair fills me with unease as yet another elected body ignores the wishes of local people.

The criticism has been severe: "A gross act of philistinism which will bring lasting shame to all involved," the biographer Sir Michael Holroyd said.

"So the library is now an unlibrary," playwright Michael Frayn added, "in the way that people became unpersons in the darkest days of the Soviet Union." Maggie Gee, vice-
president of the Royal Society of Literature, blasted the "cowardice of Brent's Labour council".

This week, Ian Whitwham - one of SecEd's finest writers - offers his poignant commentary on Kensal Rise and a saga which he rightly calls a cautionary tale for us all (see At the Chalkface on page 16).

Not able to match Ian's poetry, I will sign off by simply saying that this sad story, for me, is the epitome of thousands of other stories from across the country - vital services axed, government budget cuts blamed, local facilitie "disappeared" overnight, residents' views and wishes gnored and trampled upon. It is a depressingly common tale as ordinary people suffer disproportionately while politicians hide behind the false justification of austerity.

- Pete Henshaw is the editor of SecEd. You email him at editor@sec-ed.co.uk or find him on Twitter (@ pwhenshaw).

\section{Ofsted: We must make}

\section{sure we have our say}

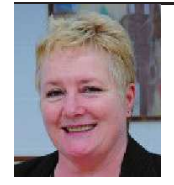

Ofsted has unveiled yet more changes to the inspection regime. London headteacher Kenny Frederick offers a commentary on the latest alterations and also a call to action to her fellow school leaders

\section{IT WAS with great interest and a healthy dose of cynicism that I studied the response to the consultation on the newest Ofsted framework, due to be implemented information for the weblink). \\ I am cynical because in my experience, what is announced (very loudly) before the consultation is generally what happens. sen by many as a "done deal" with not much hope of anything changing. \\ Our new chief inspector has been very vocal on the changes he was going to make when he was appointed. The rhetoric of his announcements, backed up by the secretary of tate, did not encourac any of us to relly believe that Ofsted would back-tack one the matters.}

This is maybe why less than 3,000 heads and teachers took the ime to respond to the consultation. However, my cynicism was displaced because there have been some changes to the proposals as result of the consultation - even if we have to look very carefully for then and take what solace we can as we hurtle though the six
weeks left of term and towards mplementation in September

The most important change are as follows: Ofsted has agreed $\begin{array}{ll}\text { that no-notice inspections were } & \text { states that there will be some } \\ \text { impractical and has moved instead } & \text { flexibility in the system to account }\end{array}$

While there have been some positive changes, I for one am disappointed that there still appears to be no understanding that punishing schools and making them out to be the enemy does nobody any good

to "short notice", with schools for events such as a recent change receiving a phone call after lunch on the day before the inspection takes place. This will enable heads to make sure they are present for the inspection and allow the school to

for events such
in leadership.

The proposals for schools to provide anonymised information of the outcomes of the most pe outcomes of the most

\section{of teachers, remains the same} Inspectors are to "evaluate the robustness of performance
management
arrangements management arrangements,
and consider whether there is correlation between the quality of teaching in a school and salary progression of the school' teachers". This will reflect on the ovact. the consultation, I for one an disappointed that there still appears
to be no understanding that punishing schools and making them out to be the enemy does nobody any good. Alienating the profession is going to lead excellent teachers to leave inner city schools, where the much higher, to work in schools with less challenge. I am also disappointed

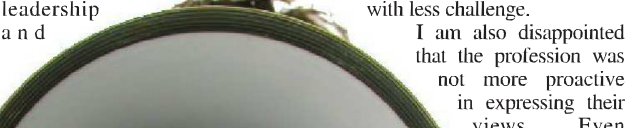
Even
the umber of responses is
similar to the feedback to the national curriculum nsultation, despair
that every inspection and allow the school to recent performance management IN RESPONSE

\section{Dear sir,}

A report on the Premier League by Sir Michacl Wilshaw, the new Orsted inspector for football: "I am determined to raise
Indards in the Premier League. This season a shocking 50 per This season a shocking 50 per
cent of the clubs finished in the bottom half of the table. Last bottom half of the table. Last The degree of complacency
thear the figure was the same. The degree of complacency
among managers and players is among managers and players is
shown by the fact that, year-onshown by the fact that, year-on-
year, half the teams are below average. This cannot be allowed to continue! To make matters worse, every season a staggering threc ( 15 per cent of the total) consistently fail to reach acceptable tandards and are given "notice to leave" the league. The fans deserve better.

Some clubs claim they do not have the resources to compete with the bigger clubs. This argument holds no sway with me because here is no excuse for failure. Let's be clear: teams such as Norwich City and Swansea City have finished the season in a midtable position and are therefore merely "satisfactory" because their performance is "broadly in line th national averages"

This is not good enough. They need to improve next year because I will not tolerate a team that is only "satisfactory" for two season only "sa
running.

Standards must be raised. So I have set a three-year programme of targets for all Premier League eams. Next year every team must finish in the top half of the table.
It is simply not acceptable that teams are allowed to continue to be below average. The following year I expect every team to finish in the top four and win a place in Europe. Finally, in year threc, I expect every club to finish firs and win the title: only then can I truly be assured that standard are as high in football as I am demanding from schools."

Mr B Warren

Headteacher, Summerhill School, West Midlands 
CHILDREN IN CARE

\section{Young \\ people \\ in \\ care}

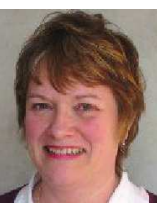

What can schools do to help children in care and leaving care to aspire to further and higher education? Gerri McAndrew explains

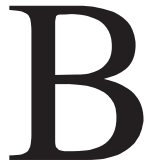

uttle UK, the charity of which am CEO, held a conference la further and high rom said that a teacher had told her I am sure this attitude is the likes of her". While damagin

The educational outcomes for care-leavers are 13 peported to be poor. For example, in 2011 only or more $A^{*}$ to $C$ grades at GCSE or equivalent.

While the issues that prevent young people in our care system succeeding are complex, I believe that there is much that can be done to improve their situation. At the core of this belief is the knowledge that young people leaving care have both the ability despite what may appear to be evidence to the contrary. But perhaps I should start by giving you a little background as to how we, at Buttle UK, got Buttle UK

Buttle UK make grants to support individual our programme helps very vulnerable children with the costs of
staying in training or college. Back in 2001

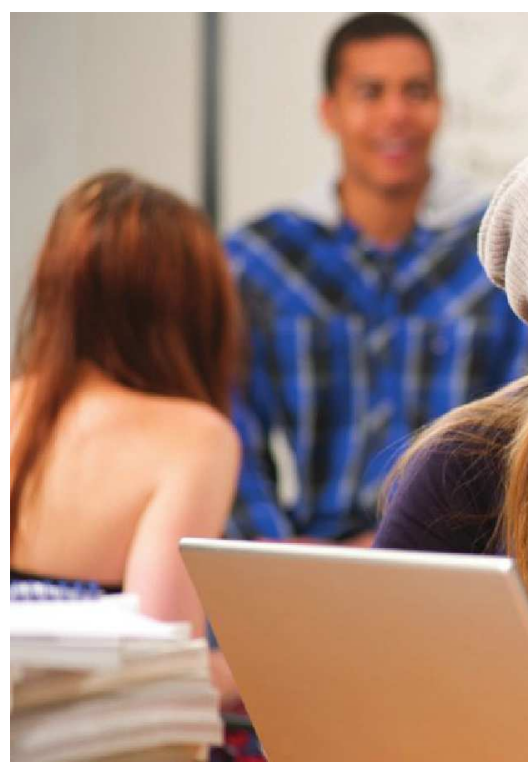

became clear to us, through the applications we were getting from care-leavers, that the issues they faced were very different from the majority of students. So we began work on a piece of research and challenges faced by this group in getting into, and staying in, higher education.

The research uncovered a systematic underestimation of the ability and potential persistence regardless of poverty, ill health and persistence regar
family problems.

Psycho Babble

\section{Inspiring independent learning}

THE OTHER day I sat across from three teenaged the individual interests of every student immediately boys on a bus. They were chatting about the jubilee celebrations and the conversation turned to the Tower
of London and the kings and queens who had been held or beheaded there.

A minor argument ensued, at which point all three got out their phones and began to Google. They

leant over one another, reading each other's

screens, and had what I would

The immediate access to information

we now have has got to be a good

are constantly bringing out the iPad

to counter an argument or prove a
fact, and even my seven-year-old is

Googling for information.

For example, on the back of a comment by a presenter during into why Poland had been invaded so many times in its history. H
joyfully recounted his findings various friends the following day. If I'd told him the answer, I doub

he would have been as interested.

of reasons. First, immediately satisfying curiosity can, according of thinking, inspire interest, promo and a genuine enthusiasm can fade away if it is no learning, and aid retention and memory. An interest is often driven by enthusiasm or excitement and emotionally charged learnin (where the emotions are
much easier to remember.

Second, individual interest is associated with a psychological state of "positive affect" an learning. Third, interest sparks independent learning. which has been proven, to enhance memory and conprehen on all levels.

Determination is the product of interest and enthusiasm and wanting to know an answer fo personal reasons is an important means of inspiring implement this research in the classroom. Larg implement this research in the classroom. Large
classes do not allow the average teacher to respond to may learn more than one way

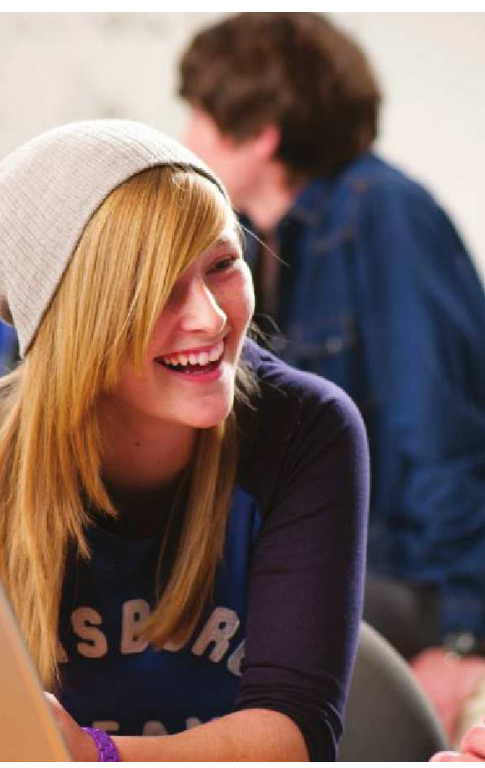
and higher education, but that not enough was bein done to encourage them to try, or to help them
to stay there once they did. When we shared our research with a group of university vice-chancellors, they were shocked and committed there and then to do more. Out of this the Quality Mark for Care a further and higher educational institution offer basis for the assess care and care-leaver applied for and succeeded in obtaining the awar and the scheme is now being rolled out to the further nurtured.

While many classrooms do contain technology, not all make use of it to promote independent and children are encouraged to find and check fact and children are encouraged to find and check fact the available computers, as and when required. The satisfaction achieved by successfully gaining information also inspires confidence and the act then much more Obviously some subjects lend themselves more easily

The research uncovered a systematic underestimation of the ability and potential of care-leavers, overcome only by their resilience and persistence regardless of poverty, ill health and family problems mathematical concepts before reporting back. The fact that this type immediate result will enhance the motivation to continue; the fact that children mindset and boost learning. Although there is no question that classroom activities are curtailed to some invested in working out ways that student an work independently, upon their own interest and with access to technology that will provide mediate answers, will undoubtedly reap rewards. We live in an information-rich instant-access age that our students are increasingly interested in do this, taking advantage of interest and enthusiasm, even reluctant learners will begin to take part and, most importantly, learn.

- Karen Sullivan is a best-selling author, psychologist and childcare exper.
So we concluded that it was not the case that care leavers were not capable of getting into furthe eavers was born.

The aim of the Quality Mark is to provide ramework for validating the quality of support that strategie

Since we launched the Quality Mark in 2006 more than half of the universities in the UK have

\section{support - that
very difficult.}

By encouraging looked-after students and showing them that it is okay to share this information with those that can help them (and that it will be kept confidential), then these stud the can increase their chances of getting to there or university and their chances of staying The next question is whether schools offer any pport that is tailored to looked-after children's It is worth considering why looked-after children need special support in this area. The answer is
that some 16-year-olds may have left care. They therefore have to become independent much sooner in life than their contemporaries and this makes them more vulnerable. Many are vulnerable already of course, and it may be that due to the nature of the is already supporting them through counselling or other pastoral support

However, in considering their progression from school at 16, there are some particular questions that the school must answer - do they know what support the students are entitled to from their local authority, where will they be living, and whether there is additional funding that they can access? Hopefully schools are already involved in Pathway Plans and Personal Education Plans, which local authorities have a duty to produce for the young people that are leaving their care. But if not, the virtual head within the local authority can advise on this. Alternatively, you could contact universities and colleges in your area, particularly those with the Quality Mark, as this is something that these institutions will also be able to advise on. They can from school to 6th form, college or university is less daunting and smoothe

Universities and colleges are judged in their Quality Mark application on how they engage with a range of key institutions, including schools. Through this outreach work, we expect them to make available relevant information, advice and guidance (including financial support) about progression to and study options at further and higher education, and to ensure that this information is accessible
to those in care through things like taster or open to those in care through things like taster or open
days and summer schools. We also expect these institutions to effectively publicise the support they institutions to effectively publicise the support they
offer to potential students with a care background. Schools can help their care-leavers by ensuring that this information is available to them, and encouraging them to access the opportunities that encouraging them to access the opportunities that
these colleges and universities are offering. By providing the right sort of tailored support looked-after children, and encouraging them to access what is available, schools can help make the challenge of taking the next step in education less overwhelming. This in turn can make a huge difference to them in accessing what we all believe to be essential for adult life - getting the best
possible education. - Gerri McAndrew is CEO of Buttle UK. $\begin{array}{ll}\text { children are reluctant to identify themselves as such } & - \text { Gerri McAndrew is CEO } \\ \text { to the colleges and universities to which they might } & \text { Further information } \\ \text { want to apply. } & \end{array}$ This is understandable, but it makes providing 


\section{Depending on Dunkirk}

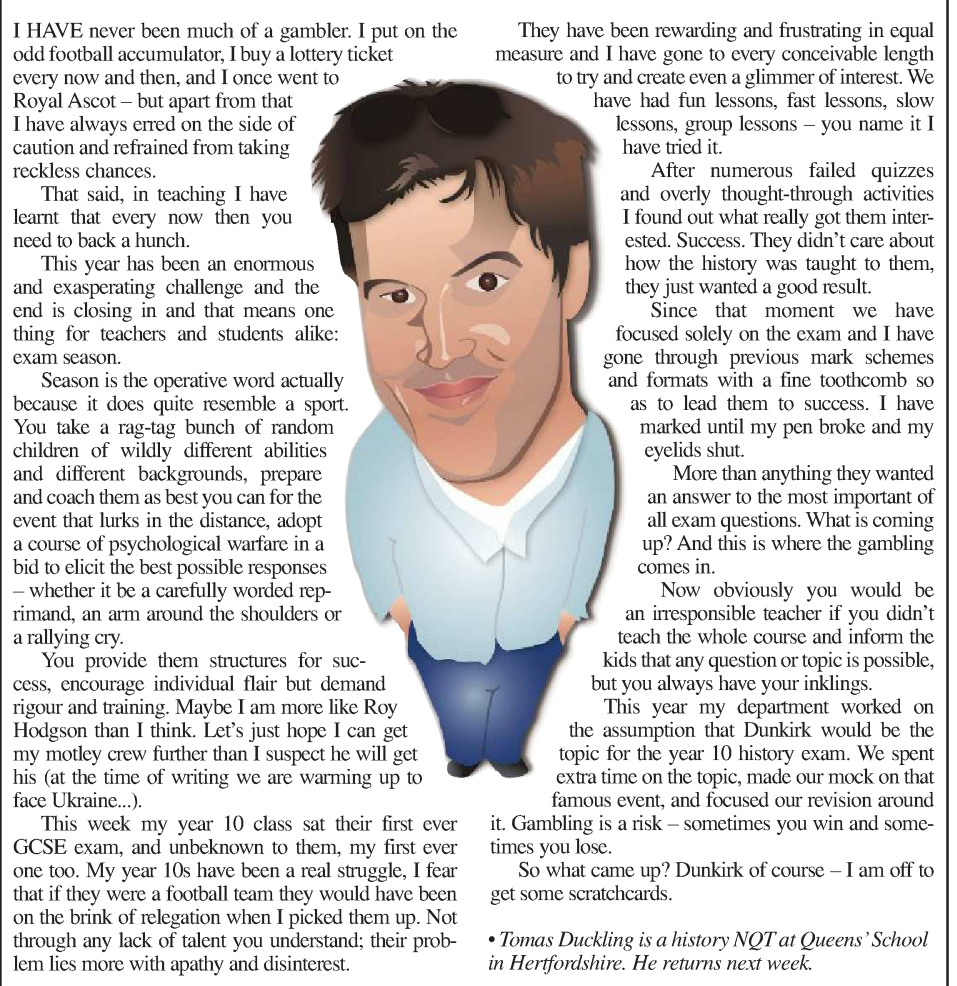

Teach it like Torno!

\section{Testimony}

"Example is the school of mankind, and they will learn at no other." Edmund Burke.

FOR MORE than six weeks now year 9 has been learning about the Holocaust and, as is the norm in ou school, we took a trip to the Imperial War Museum the week before half-term.

It usually runs smoothly with the students vi iting exhibitions on the First and Second Wor Wars before contemplating the Holoc experience. I use the word contemplat-
ing because it is indeed very much a spiritual experience and one that, for many students, really ignites their interest in history.

For any of exhibition, you will know about the various horrors on show, such as the Zyklon B gas pellets or the table on which many Nazi experiments were
carried out. But what moved many of my students was a poem written by
Jewish girl, Marisia, who was friends with a Catholic girl, Dosia.

The sheer beauty and humanity of the poem and sketches was what caught the visible nightmares on show. The looking back on days of friendship and innocence.

However, the real impact came when the students received a talk cators. She talked to us about the years of Nazi persecution the reading from a book about a girl who went into hiding.

At the end of the reading she said to . "That little girl is sitting in front of survivor of the Holocaust."

You could have heard a pin drop and I am not ashamed to say that I, too, had a

lump in my throat. To be told the story by someone who was mine actually expewh in the clas extraordinarily powerful way for my students to begin extraordinarily powerful way for my
to come to grips with the Holocaust

to come to grips with the Holocaust.
Needless to say in the followin dents requested that they be able to whe my stthemselves to express the impact that she had had on them. And though some only wrote short pieces a opposed to the two or three pages that
their sentiments were all very similar.
One student actually confessed: "Before I came because I wasn't there, but as soon as I heard your story I could see there was something miraculous about you."

The students will now have a follow up visit by one of our regular speakers and another survivor of the Holocaust, Rudi Oppenheimer, during which a
bench will be dedicated to his continuing work with our school.
We often hear the word "impact" mentioned in schools today. The impact of these types of experiences are dif-
ficult to measure, but are among the ficult to measure, but are among the dent can have. Often we have past students coming back recounting their memories of the day they met a Holocaust survivor and it is clear that the impact

For my own part the uear when I will accompany
our year 10 students on a
visit to Berlin in two weeks' time when we will come facecamp, Sachsenhausen, as well as visiting the building in which the Final Solution was agreed upon. I will then be travelling to Poland with nother school that I work with in July. There we will be visiting Auschwitz July. other places. For these students as well as myself the real impact of education will be felt, and though this is something they may not be able to take into the examination room, their experinces will no doubt play some part in shaping

Being a classroom teacher remains the greatest privilege hat we can have in this profession as we have the opportunity to impact on the lives of those the reasons why we entered the classroom in the first place and look to continually build upon the experiences that both our students can gain as well as ones ences that both
for ourselves.

- David Torn is a professional tutor at St Edward's London and co-author of Brilliant
Teacher. He returns in two weeks. learning journey continSchool in Essex. He is a former Teacher of the Year for

Students'

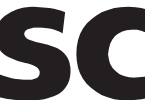

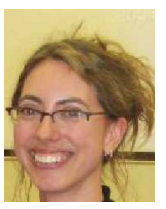

\section{Professor} Louise Archer reports on research into the attitudes of young students towards STEM subjects and careers as they move from primary to secondary - and the implications for key stage 3 teaching

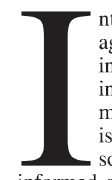

nternationally, there is a widesprea agreement that more needs to be done to increase and broaden post-16 participation in science, technology, engineering an is not only important for ensuring that societies have a broad base of scientifically supply of STEM professionals for the future.

ASPIRES is a five-year, longitudinal study xploring science aspirations and engagement among 10 to 14-year-olds, as previous research indicates consolidation of children's views on science.

The ASPIRES project is funded by the UK' Economic and Social Research Council (ESRC) as part of the Targeted Initiative on Science and Mathematics Education (TISME)

Our study includes an online survey (administere when children are in years 6,8 and 9) and repeat interviews with a sub-sample of children (tracked in years 6,8 and 9 ) and their parents (interviewc
twice, when their children are in years 6 and 9 ).

In Phase One in 2009, the online survey was completed by more than 9,000 year 6 children $(10$ and 11-year-olds) from 279 primary schools across
England. We also conducted 170 interviews with England. We also conducted 170 interviews with
78 parents and 92 year 6 children, drawn from 11 78 parents and 92 y
schools in England.

In Phase Two last year, the survey was completed
schools in England. by 5,634 year 8 students (aged 12 and 13) from 69 secondary schools across England. The second round of interviews (following up the children, now in year 8) is currently being completed and is due
next month (July 2012). The key findings so far are next month (July 2012). The key findings so far are

Most children like school science

We found that in both the first and second surveys, children report enjoying their science lessons. Year 8 pupils rated science as their fourth most popular subject
the most popular being design and technology, then English and mathematics).

Similarly high proportions (more than 70 per

5 We were struck that, despite liking science, less than 17 per cent of year 6 pupils agreed that they would like to become a scientist. By year 8 this has fallen further, to 14.5 per cent, although other STEM careers are more popular, such as engineering, inventor and medicine

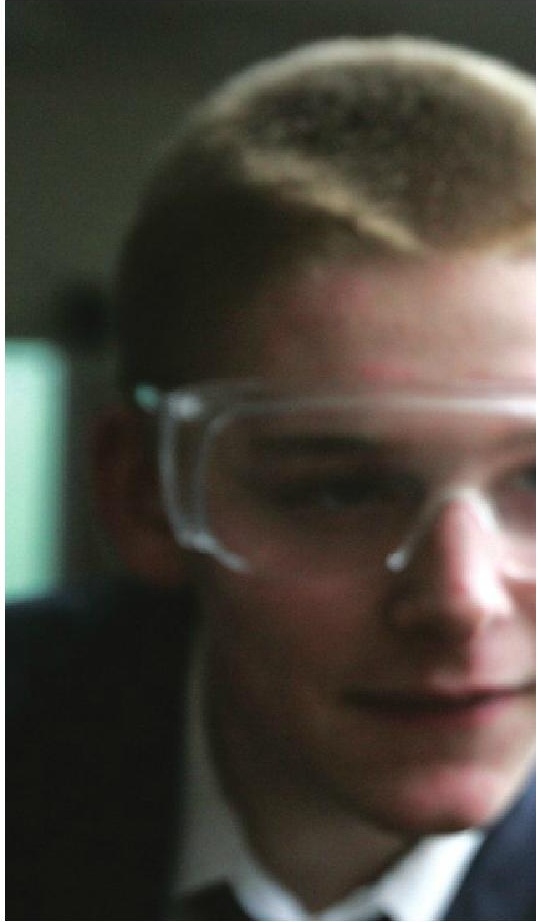

interesting things in science. Around 80 per cent of year 8 pupils also agree that they have enthusiastic science teachers and that their teachers care if pupils A ton lessons and expect them to do well. science teacher and 82 per cent believe if they study hard they will do well in science (with 69 per cent feeling that they do well in the subject). Only 19 per cent said that they find science difficult.

Our provisional impressions from the followup interviews currently being conducted with year 8 pupils confirms this view - with most students saying that they enjoy science classes in secondary Children have positive views of science In line with findings from year 6 pupils, year 8 children express largely positive views of science and science careers. For instance, 73 per cent agree that science is
generally useful for their futures and 70 per cent feel that science is useful for getting a good future job.

Year 8 children also seem to have positive views of careers in science, with 79 per cent believing that scientists do valuable work and the majority agreeing make a lot of money ( 63 per cent).

Few children envisage a career in science We were struck that, despite liking science, less than 17 per cent of year 6 pupi

By year 8 this has fallen to 14.5 per cent, although other STEM careers are more popular, such as engineering ( 25 per cent), inventor ( 26 per cent) and medicine ( 35 per cent). When asked to rate a sample spread of future career options, the most popular (39 per cent), arts/actor/dancer/singer ( 53 per cent) and business (the most popular, at 62 per cent).

We found that despite liking school science, only 43 per cent of year 8 children agreed that they would like to study more science in the future. When asked to identify the most important reasons for choosing subjects to study in the future, more than three quarters ( 76 per cent) identified the usefulness of a subject for their future careers as being the first or most important factor.

Only a fifth thought that "how well I do in the subject" would be the most important consideration when making subject choices, with less than 15 per cent citing enjoyment of the subject as the key reason. This suggests that children's interest in science does not translate simply into aspirations to Given that perceived usefulness seems to be an important factor in children's subject choices, it was also notable that in the interviews, year 6 children (and parents) tended to see science qualifications as only leading to a narrow range of careers - notably,
scientist, science teacher or doctor. 


\section{Is this the year for 3D?}

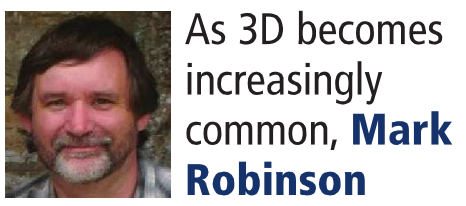

argues how this popular technology could be used in the classroom to change the face of the learning experience

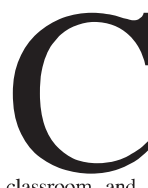

onsumer technologies are environments and are having a major impact on the way that young people learn. Students are accustomed to using technology in classroom and are tuned into new developments, including 3D through its regular use in movies and By tapping into this natural understanding and interest, 3D usage in secondary education not only emulates experiences in the outside world, but also helps prepare pupils for the workplace and provides a more engaging learning experience.

The challenge for schools is how they can adapt teaching practices and materials to move from paper and $2 \mathrm{D}$ to $3 \mathrm{D}$ teaching.

\section{$3 \mathrm{D}$ in the modern workplace}

As well as the increasing use of 3D in cinema and media, it is also important to note its place in industry and business. Many sectors are highly reliant on 3D by the nature of the work that they do.
For example, in the automotive industry, 3D models help to pinpoint complications or faults within the structure of a vehicle, allowing advanced testing and enhanced understanding of the systems to inform future innovations.

In medicine, surgeons use 3D visuals of the human body to plan and prepare for operations. In addition, the wider manufacturing, oil and gas exploration and the engineering sectors are increasingly reliant on $3 \mathrm{D}$ in exploration, research, and design and testing.

at pupils take away skills from the classroom that are transferable to the workplace. In the classroom we should be preparing students for their role in a global 21 st century society and equipping them to contribute to economic growth and innovation. Clearly, being able to understand and fluently use technology such as 3D is vital and it is important that we prepare pupils for this by using it effectively in the

There are many projects that promote these benefits.
classroom. The recent Big Bang Fair in Birmingham illustrated to students that $3 \mathrm{D}$ is prevalent in the workplace of the science, technology and innovation sectors. In programme built around the bid to break the $1,000 \mathrm{mph}$ land speed record) uses 3D to stimulate pupils' interest in science and engineering, bringing concepts to life in science and engineering, bringing

Creating active learning environments

Traditional paper methods are being challenged both in schools and the outside world. 3D inspires and engages pupils and it also creates a much more interactive perience.

It is a misconception that $3 \mathrm{D}$ is passive or simply something that you watch. On the contrary, in the secondary classroom it provides numerous opportunitics for students to become active participants and to question, challenge and interact.

This is most easy to see in the STEM subjects. For example, a whole cell can be dissected and analysed in much more detail than can be achieved through a 2D diagram and using a $3 \mathrm{D}$ version of the human body creates a stronger reality for students.

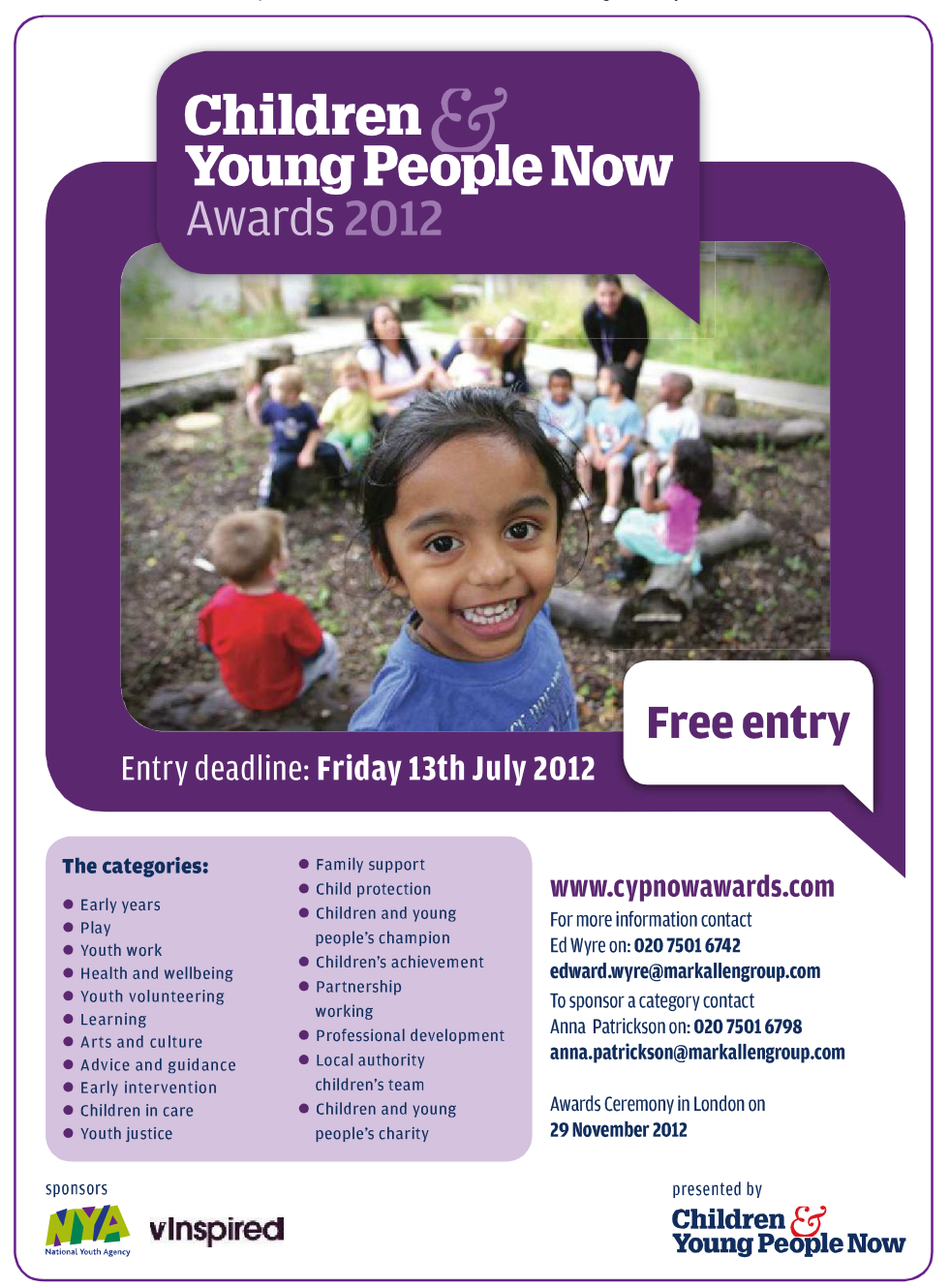

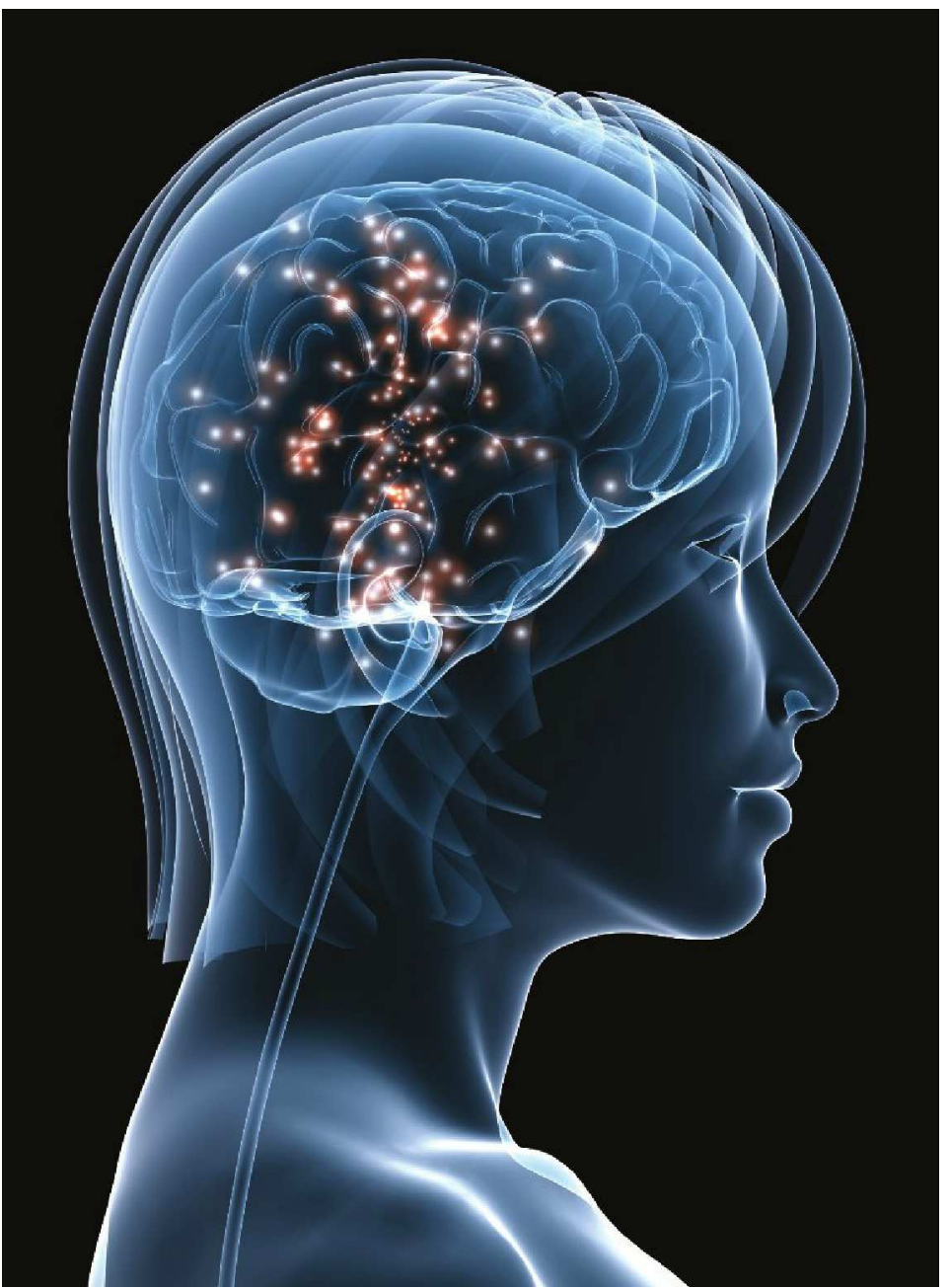

Other modern advances such as depth sensing cameras, like those found in devices such as the Microsoft Kinect, can sense full body movement in 3D pace and are changing how we interact with digital

Companies such as Small Lab Learning are arnessing these new interfaces to "embody" the learning - what better way to understand inertia or "g-forces" than by actually moving around?

Recent research, such as the $3 D$ in Education White Paper written by Professor Dr Anne Bamford, director of the International Research Agency, is reinforcing he view that 3D helps individuals and classes to delve deeper into subjects and gain a more complete eem intangible when presented as flat pictures on paper.

One example is by using 3D visual simulations of life in the trenches during the First World War, which immerse the students in the sights and sounds of the battlefield to help them gain a different perspective in istory lessons.

It also has the added benefit of appealing to users of varying abilities, making the class more inclusive and also offering an array of new ways to engage those with certain SEN.

How can schools incorporate 3D?

Despite arguments that demonstrate the impact of 3D and its effectiveness, many schools will question how, on limited budgets, they can afford to invest in 3D and Mise it to its full potential.

Many schools will be unaware that they already have he infrastructure to support 3D. For example, a lot of hardware in existence in their classrooms, such as the projectors supplied with their interactive whiteboard may have DLP chips (digital light processing) or be marked "3D-Ready", meaning they have been futureproofed and are already prepared for 3D usage.

Users will then just need to ensure they have PC with a suitable graphics card and acquire the 3D glasses to complete the solution.

Any provider of educational 3D content will be ble to advise you on how to maximise the projectors and interactive whiteboards that you already have in your classroom.
3D resources that match curriculum needs are is some content already available free of charge on platforms such as Promethean Planet and teachers can benefit from large online resources such as Google Sketchup and the Google 3D warehouse - when combined with a 3D projector and software this allows users to find or draw objects which are then translated into 3D.

It is also vital that teachers, and ideally students, share resources for 3D to harness its full potential within the classroom.

Although these resources are readily available, the true challenge is for schools to commit to using the content and investing time to develop and tailor For teachers already innovating with 3D, the benefits more compelling.

The year for 3D?

It is an exciting time for teachers, schools and students embracing 3D and I believe that this is the year to consider implementing it practically in secondary education. and that there is enthusias for it. It is increasingly becoming not just "nice to have", but a necessity in "nice to hav", but a necelty tive to benefit studin in the future

Furthermore, many schools already have the basic technological elements to be able to use 3D and all upgrades should now incorporate 3D capabilities. The foundations are laid for the future use of $3 \mathrm{D}$, but in order to fully harness its power, content must now be new ways of building it into lesson plans to create a truly engaging learning experience. SecEd

- Mark Robinson is group head of education product strategy at Promethean

Further information

To down the $3 D$ in Education White Paper referenced above, visit http://dlp.com/3dresearch needed to keep content fresh and relevant. There resources to fit in with the curriculum and lesson plans. generated to support its use in classrooms and discover 


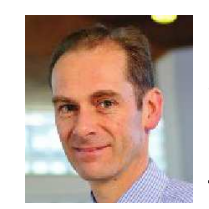

Geoff Coombe discusses the new vision for the teaching of computer science in schools and argues why academic knowledge and practical skills must combine to equip students for the future
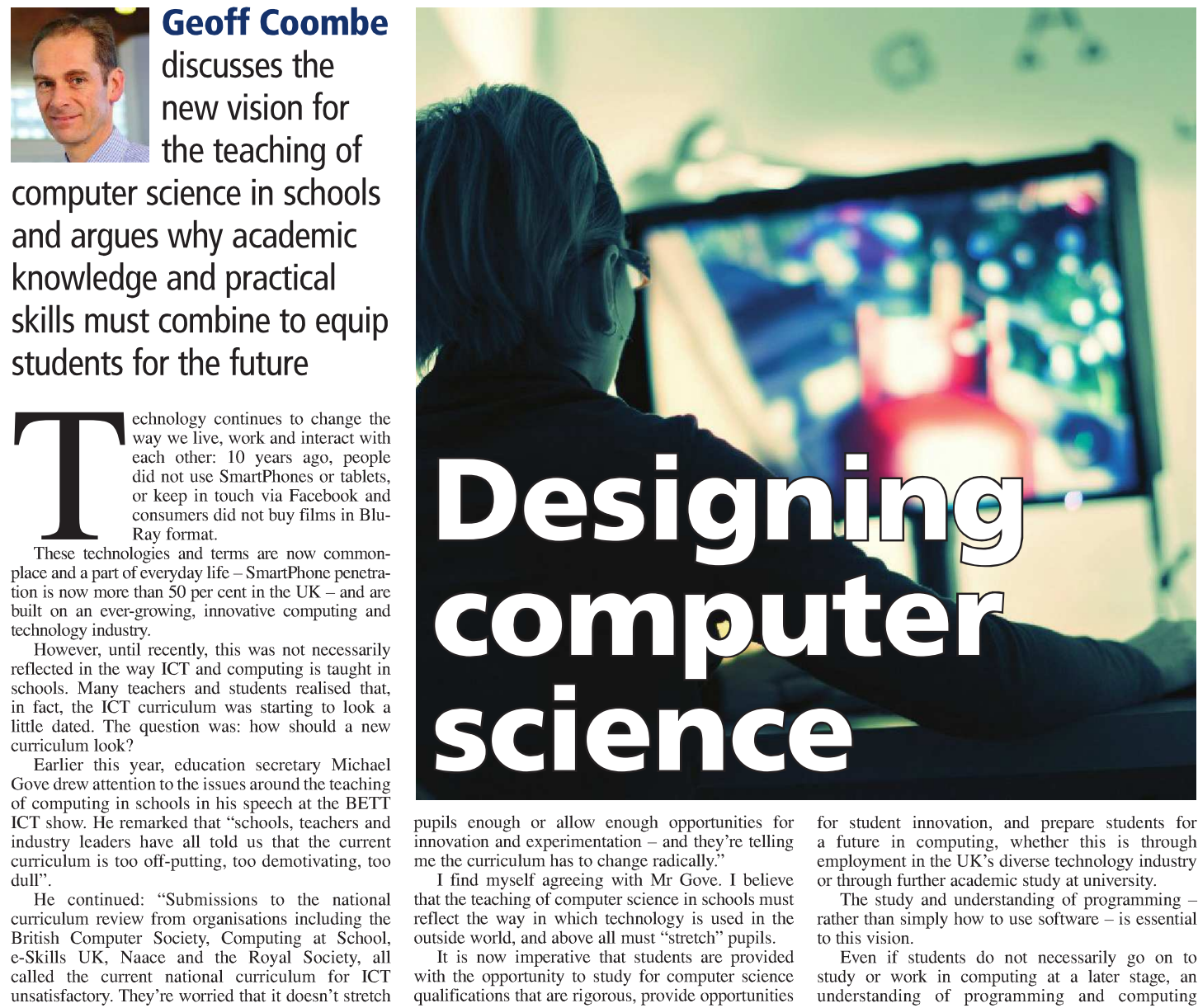

pupils enough or allow enough opportunities for for student innovation, and prepare students for innovation and experimentation - and they're telling a future in computing, whether this is through me the curriculum has to change radically." 1 employment in the UK's diverse technology industry I find myself agreeing with Mr Gove. I believe that the teaching of computer science in schools must reflect the way in which technology is used in the its world, and above all must "stretch" pupils. with the opportunity to study for computer science qualifications that are rigorous, provide opportunities The study and understanding of programming rather than simply how to use software - is essential to this vision.

Even if students do not necessarily go on to

tudy or work in computing at a later stage, an understanding of programming and computing principles supports further study and careers in other ficlds such as statistics, mathematics, the creative industres and the sciences - for example, many scientists use programming to build scientific model and tests.

For this reason, I believe that a computer science syllabus should be designed in such a way that it provides both a solid academic grounding and the practical skills that will support student innovation.
The syllabus should cover key computing concepts The syllabus should cover key computing concepts and the fundamentals of programming; while at the same time providing students with the skills an facilities to create applications, for example using mobile and web technologies, as well as computer

Students must not just emerge from schools with
games. a sound understanding of computer science, they must be able to put their knowledge into practice. We must foster a creativity that goes beyond clip-art and animated presentations; a creativity that will go on to fuel the rapidly expanding technology industry in the UK.

I believe that the key to ensuring the syllabus achieves this balance is by enlisting the help of third parties, in particular the universities at which students will go on to study computer science, and stakeholders from the computing and technology industry.

At AQA, we are working with Microsoft with the aim of ensuring that our GCSE in computer science will equip students with the skills and knowledge expected by employers in this sector. We have aligned its syllabus with the Microsoft Technology Associate (MTA) developer qualification, part of an industry standard.

According to a recent study by e-Skills, the UK IT industry needs to see 550,000 new entrants to its workforce in the next five years to support the growth of the IT market. Putting programming and practical kills at the heart of the computer science curriculum is essential if we are to meet this demand.

By equipping students with the ability to apply their equipping students with the ability to apply thir a surge of in cienc, but celne, bus will, in the future, drive growing

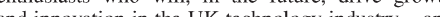
and in SecEd - Geoff Coombe is director of general qualification development at $A Q A$.

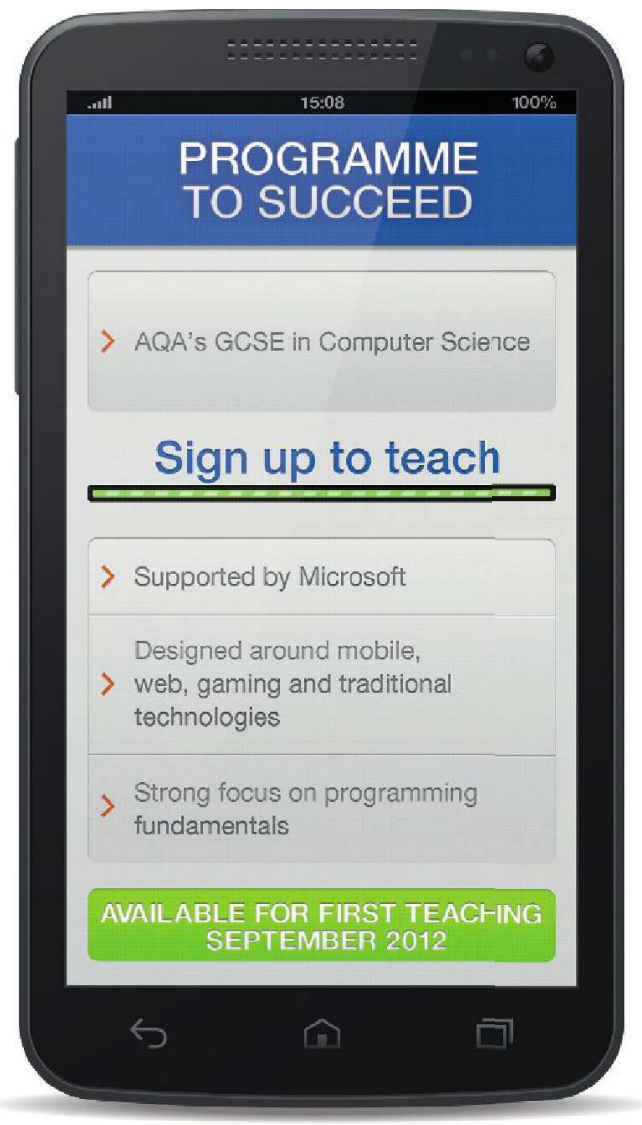

Using today's technology to create tomorrow's programmers.

Sign up for your:

- own personal subject adviser

- a range of free AQA teaching and assessment resources

- a suite of free Microsoft resources.

aqa.org.uk/programmers
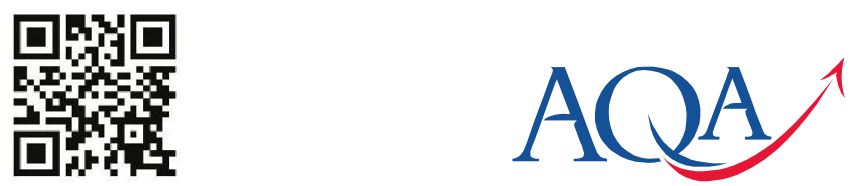


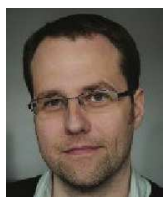

With fees set to hit $£ 9,000$ and no rise in the proportion of state school applicants to the top universities, Dr Steven Jones reports on a proposed remedy that may actually be part of the problem
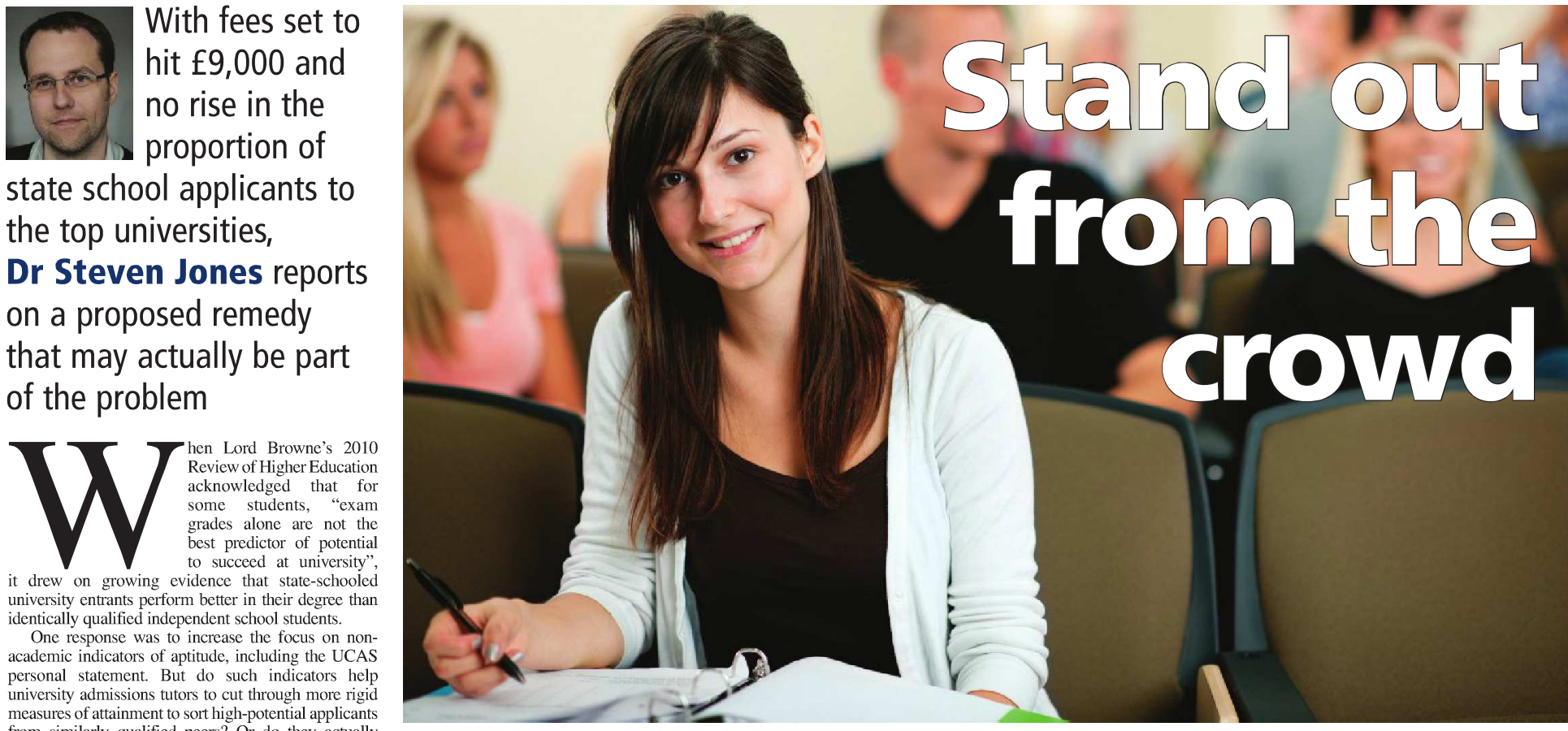

evidence that state-schooled university entrants perform better in their degree than identically qualified independent school students. academic indicators of aptitude, including the UCA personal statement. But do such indicators help university admissions tutors to cut through more rigid from similarly qualified peers? Or do they actually credentials further?

Speaking in April 2011, universities minister David what that individual's potential might be."

Previously, he had given examples of the kind Previously, he had given examples of the kind
of indicators that might be used: "Things such as applicants' CVs, personal statements and their potential to benefit from a particular course."

However, closer inspection reveals that these three indicators soon collapse into one. Applicants don't submit a CV (they simply complete a series of charactelimited fields with factual information), nor do the

database was made up of 309 personal

The UCAS website offers sever pages of adve bout how to compose a personal statement, including a list of dos and don'ts, a how-to video and a mindmap PDF. Snippets of advice are provided from a series of admissions tutors, often underlining the importance of "English language and grammar at a standard suitable for entry to higher education". Several unaffiliated student websites provide sample statements for applicants to consider and in recent years a number of how to" books have appeared on the market.

However, writing a personal statement can prove to "stand out from the crowd", but, by definition, this is

\section{Even though all applicants would later prove} themselves to be of similar academic ability, a clear distinction emerged between those from independent schools and grammar schools and those from 6th-form colleges and comprehensive schools. For every one error found in the personal statements of the former, no fewer than four were found in the latter

comment on their suitability for individual courses Only the personal statement - a 4,000-charactc

- can be used to assess potential.

Unfortunately, academic research on this topic is statement, mostly conducted by university medic schools, find little correlation between the quality of the application and the subsequent achievement of

More alarming is that no study has examined the connection between applicants' schooling background and the nature of the personal statement they submit. This despite the 2004 Schwartz Report speculating that the personal statement cannot be seen as the applicant's own work"

To address this gap in knowledge, I began cocting some data of my own. I took one large to courses in and economics) and obtained the personal statements submitted by all 5,276 applicants for 2010 entry.

To keep comparisons fair, I needed to control for academic achievement. Meaningful conclusions could not be drawn by comparing very strong students with ma at A level. All overseas applicants were eliminated, as were all applications from mature students.

The remaining statements were tagged according to the type of school the applicant according to the type of school the applicant
attended. Comprehensive school, 6th-form college and independent school applicants each comprised a similar share of the database; grammar school
applicants a slightly smaller proportion. The final not something that every candidate can do. Indeed, even when it comes to superficial features of the statement, major difterc

In order to examine applicants' standard of written English, the database was searched for clear examples of spelling and punctuation errors. Prescriptive rules of English, such as that involving the split infinitive, were

Even though all applicants would later prove themselves to be of similar academic ability, a clear distinction emerged between, on one hand, those from independent schools and grammar schools, and, on the other hand, those from 6th-form colleges and comprehensive schools. For every one error found in the personal statements of the former, no fewer than four were found in the latter (see graphic 1).

Even more interesting was the distribution of nonquantifiable linguistic errors. These blunders were not so much about misplaced apostrophes or poor punctuation, but rather involved more subtle forms of inappropriateness. For example, one 6th-form college applicant, clearly reaching for an academic register aforementioned points all advocate my academic and enthusiasm for this course"

Another applicant from the same background took the opposite route, underestimating the level of formality expected in the genre: "I am not really sure what makes me so interested in the subject; I don "t have
an exact reason to be truthful. I love it as a whole. Most an exact reason to be truthful. I love it as a who",
of all I love getting to the bottom of a puzzle." re-sitting two mombiguous mistakes such as "I am aquired" were counted.
Clearly, neither applicant understood the conventions of the genre or

If differenct

ifferences were limited to presentational wowever, well as appearance.

For example, when encouraged to talk about Fevant work experience, many responses were mited to school-facilitated opportunities and trips. "In year 11 we were taken on a school trip to Cadbury "In yer GCSE year the was an applicant. "In the tha GCSE year there was an opportunity for a group of college applicant.

On the other hand, independent school applicants were often found to draw on a wide range of placements One 18-year-old listed no fewer than seven: modelling for a London designer, trading for a firm of broker working for a BBC radio station, events planning with marketing team of a leading law firm, and managing small gastro-pub.

ox Quantifying the array of work experience reported was not easy, but an estimate of the total number of oles, visits, placements, volunteering activities and school applicants' statements boast about 50 per cent more than tants" statements boast about 50 per cent than those from applicants of other backgrounds. Furthermore, the nature of the work is very different. applicants, the work most likely takes the form of "job": paid, low-prestige, low-relevance and low-skill. For independent school applicants, the work kely to be an "experience": unpaid, high-prestige, high-relevance and high-skill. Indeed, the "jobs" to between the two groups (see graphic 2 ).

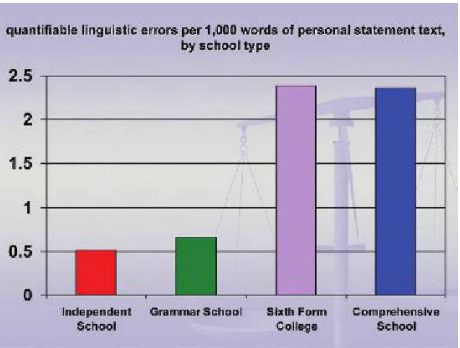

Graphic 1: A catalogue of grammatical errors in university application persona rrors in university application personal
statements by candidates' school type

Findings therefore echo a recent report by the Education and Employers Taskforce, which drew on and quality of the work experience received by 987

For those who attended independent schools, 42 per cent reported that work experience helped them secure a place at university (and 13 per cent felt it proportion fell to 28 per cent (and 11 per cent), and for proportion fell to 28 per cent (and 11 per cent), and for
those at comprehensive school only 25 per cent felt that work experience was of benefit (and just six per cent The rit helped them a lot)

The respondents were all young people who had the difference is that process while others did not.

When it came to extra-curricular activities, the pattern was similar. To borrow Bordieu's terms, independent school applicants often drew on cultural capital ("I did a Cordon Bleu cookery course at the Tante Marie School, in London"), social capital "visiting my uncle in America, observing his aircraft brokerage and marketing company"), and economic capital ("during my gap year I plan to do a ski season in Méribel").

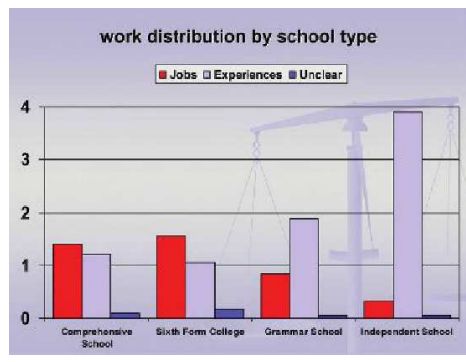

Graphic 2: The 'jobs' to 'experiences' ratio for students by school type

However, in the absence of such opportunities, applicants from 6th-form college and comprehensive schools drew on less genre-appropriate activity

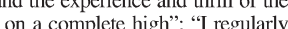
watch Match of the Day and I enjoy the diversity of the Champions League"; "sometimes I just go on walks

While one could argue that the wider range of work and life experience drawn upon by independent and grammar school applicants make them better suited to undergraduate study, one must acknowledge that these opportunities are ultimately the product of advantage. Non-academic indicators of potential, such as the personal statement, are not a proxy for "fairness". Indeed, if greater attention is paid to such indicators, existing inequities in the educational system will only be reinforced at the point of university entry. There are ways in which the playing fieds be levelled. For example, opportunities for stateexp expetion. The aesont sector. The personal sta

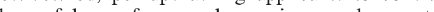
curricular activity only.

(to huge and better solution, therefore, may be to do away with the personal statement entirely, and rely instead on

- Dr Steven Jones is a senior lecturer in the School of Education at Manchester University. You can email him
at stevejones@manchesterac.uk 


\section{Twelve governing top tips}

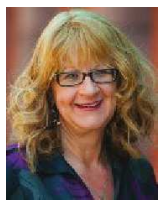

Karina Carter, a chair of governors and a National Leader of Governance, offers her 12 tips for governing excellence

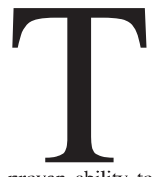

his year has seen the first National Leaders of Governance (NLGs) appointed to support what has been called the biggest volunteer army in the country. Having served for more than five years as chair of proven ability to work collaboratively and transform schools, each NLG will support chairs of governors experiences to guide our counterparts through their own challenges.

This will cover a wide range of circumstances. We

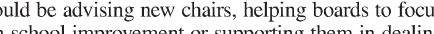
with significant strategic shporting them in dealing a federation or converting to academy status.

We will also provide coaching and support their counterparts in a variety of different ways - for example, in using data effectively to improve schoo performance or by delivering more effective support and challenge for their headteacher.

In my time as a governor, I have learned a numbe of lessons that can be applied to almost every schoo across the country.

Have the courage to change your mind My school - Stretford High School in Manchester part of a local authority that supports grammar school and which is often keen to recruit more into the system, There was also an opportunity to become an academy, and I believed this was a route that would be the right option for the school in terms of finance and capital. As we proceeded further and further down the
line, more and more difficulties became apparent, and it became clear that we had got it wrong. It was situation in which I needed to swallow my pride an admit, at the 11th hour, that we needed to go back on our original decision.

The governors and school leadership team had also come to this realisation and we were able to halt the process. This was certainly the right move for us, and although we would not rule out seeking academy status
in the future, there has been no occasion on which we have been able to see the benefit since.

\section{Governors should not} be aloof - you must take an active interest in the school and not simply issue commandments from an ivory tower

Keep your priorities clear

Ultimately, the governors' job is about ensuring the attainment of children. It is easy to be distracted by personnel issues, for example, when the focus shoul of school life must sometimes be set aside to really get involved with curriculum development and securing students' futures.

Get the best out of your headteachers

It is important that your headteachers feel they can be honest about the progress of the school, and that you heads are the professionals, but you need to be there to challenge, support and act as critical friend. You can only do that if they are comfortable communicating Build a capable team

Even for an experienced networker, this can be a rea challenge and will take time. The initial board comprised a group of well-meaning parents who ultimately viewe
the position as an extension of the PTA.

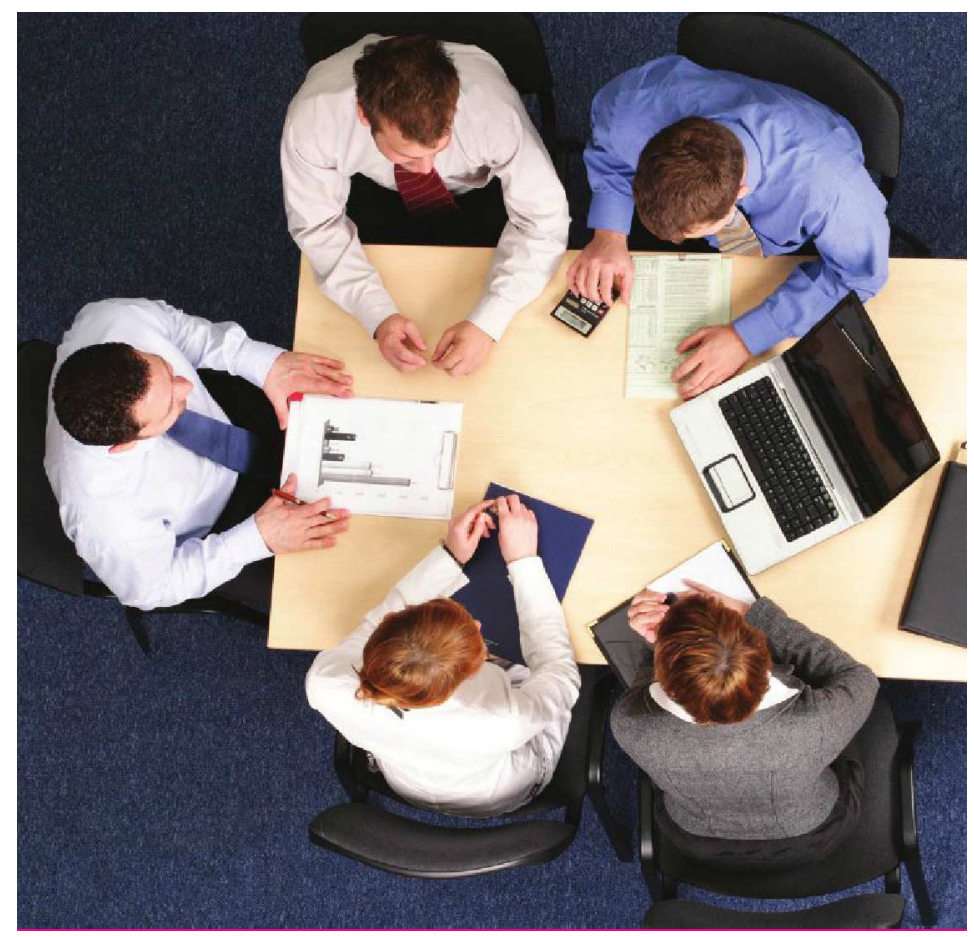

Gradually, I have replaced these with people with skill-sets that have been useful to the school: for example, one of my vice-chairs comes from a
university background and is hugely experienced in curriculum issues, while another is responsible for equality and diversity at our local Primary Care Trust, and we have brought on a number of experts from Trafford Council

Governing bodies need to move away from self-nominating groups and towards skills-based to the party.

Don't ignore what doesn't appeal

While a governing board is being built, the chairperson will often find themselves involved with issues that are outside their existing experience and expertise. Early on, I would chair finance and personnel committees and be forced to get up to speed with these areas, even if I had never encountered them in the past. However, these issues cannot be ignored and it can often be enlightening when fresh thinking is applied.

Look outside the school

When I was first appointed as chair of governors, Stretford High School was in special measures, but became "outstanding" within three years. However, the downside of this was that the school was focusing so hard on getting it right that it had become somewhat insular and had lost important links with the community. Having acknowledged this as an issue, the governors have worked hard to develop links with Lancashire and our local leisure club to improve opportunities for students and to establish the school at the heart of the

Be strategic and hands-on

It is only possible to be genuinely strategic if you know your school intimately. Of course, you must have your eye on the bigger picture, but by being hands-on, you are better placed to forge relationships and get the best out of people. As part of my role, I was involved with the strategic moves behind awarding a new catering contract, but I also run the governor welfare panel, which meets once a term with children who risk exclusion.

\section{Be vocal but broad-minded}

One of the problems affecting parent governors in particular is a dogged focus on a single issue prot afrects their child progress on wider is vitul par goveris do contribution, and do not take on the role as a vanity position and act as a passenger.

\section{Be compliant}

Confidentiality and trust are key among boards of governors. It is important to be aware that not every governor might be in it for the same reasons and

Union address: ATL

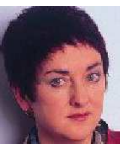

Introducing performancerelated pay for education staff would be folly, argues Dr Mary Bousted

THOSE WHO cannot learn the lessons from history are doomed to repeat them, and performance-related pay (PRP) is definitely a case in point.

UK governments have been trying to devise way to pay teachers on the basis of their performance for well over a century, from Robert Lowe's paymen by results scheme in 1862 to education secretary
Michael Gove's remit to the School Teachers' Review Body (STRB) this year - despite the fact that there is not a single shred of evidence that PRP works.

In fact, most of the research carried out since PRP's heyday in the 1980s has shown the precise opposite. The American education author and points out the insuperable problem in $\mathrm{Pay}$ (2003), point on the insustem for teachers - output is not peradily mee pay syste

This deduction was echoed by, of all people, management consultants PriceWaterhouse Coopers, whose report for the STRB in the same yea concluded: "Teaching is a professional job and performance-related pay arrangements where result enerally difficult to measure."

The implications are clear. In manufacturing or sales, where there is a direct link between targets and an individual's contribution, it may be feasible to reward performance. But when jobs become more complex, it is practically impossible to make objective, verifiable and consistent judgements. With teaching, which is a collaborative activity, we
need to question how the impact on an individual pupil's achievements throughout their whole school Recent research has upheld those conclusions of Recent research has upheld those conclusions of a is exceptionally difficult to introduce individua can be accredited to any o
Hold your management accountable This must start with knowing your facts and figures - a task that will be difficult in the beginning, but that will make you a stronger chair once you know what you

By being fully aware of your structure and targets, you will be better able to challenge senior leadership teams and ensure that you are not letting your students Be active

Governors should not be aloof - you must take an active interest in the school and not simply issue commandments from an ivory tower. For example, $I$ and other governors take part in illuminating "behaviour walks", which will often bring up issues that would have been hidden if approached by a more recognisable face.

The advice we are able to give in sub-committees has also proved valuable in bringing a business or university perspective to groups that have otherwise Demand the best!

This is at the heart of good governorship. Despite all the talk about lifelong learning, children only get one real shot at their education - if you do not get it right in the first place, it will be a lot more difficult for them to catch up when they are older.

As governors, we must see ourselves as responsible students the best possible oppent team in giving our

- Karina Carter is chair of governors at Stretford High School in Manchester and one of the first National Leaders of Governance.

Further information

For more information on the new National Leaders of Governance programme, visit www.education. governance.htm Performance pay is folly

schools, reported this year by pay specialists Incomes Data Services, showed that there wasn't any evidence performance pay had a positive effect on st
performance, attendance or graduation levels. And in the week Mr Gove published his evidence to the STRB, an examination of PISA (Programme for International Student Assessment) test data from over 70 countries, carried out by the Organisation for Economic Co-operation and Development (OECD), revealed no correlation between pupils' test results and the use of performance pay.

Since Mr Gove appears to have an ideological belief that introducing market forces of competition through performance pay will drive up education standards you might have thought that his STRB evidence would have unearthed some solid support for PRP for teachers. On the contrary, his evidence is peppered with unsubstantiated assertions, heavily qualified statements and blatant contradictions. Summarising experience with PRP in the United States, Mr Gove's evidence states "estimated gains in test scores associated with the judicious use of salary incentives were modest", while in Sweden, which of individual pay for ferociously complex system evidence that these had led to better outcomes.

Despite a bibliography spanning five pages, $\mathrm{Mr}$ Gove's submission to the STRB is overwhelmingly evidence-free.

The logic is inescapable. If a viable system of PRP in teaching were possible, then, in the decades of discussion over this issue, it would have been identified and replicated across the sector By returning to it at this stage, the government has demonstrated that it is more concerned with cutting costs than raising standards.

But perhaps Mr Gove's approach to teachers is best illustrated by the response to his own question on how to raise the status of the teaching profession. Although this question formed a specific part of the remit to the STRB, Mr Gove's submission makes no attempt to answer it. He evidently believes that all he has to do to raise their status is to cut teachers' pay, make it harder for them to progress in their career and keep up a continual barrage of criticism, and then

- Dr Mary Bousted is general secretary of the Association of Teachers and Lecturers. Visit 


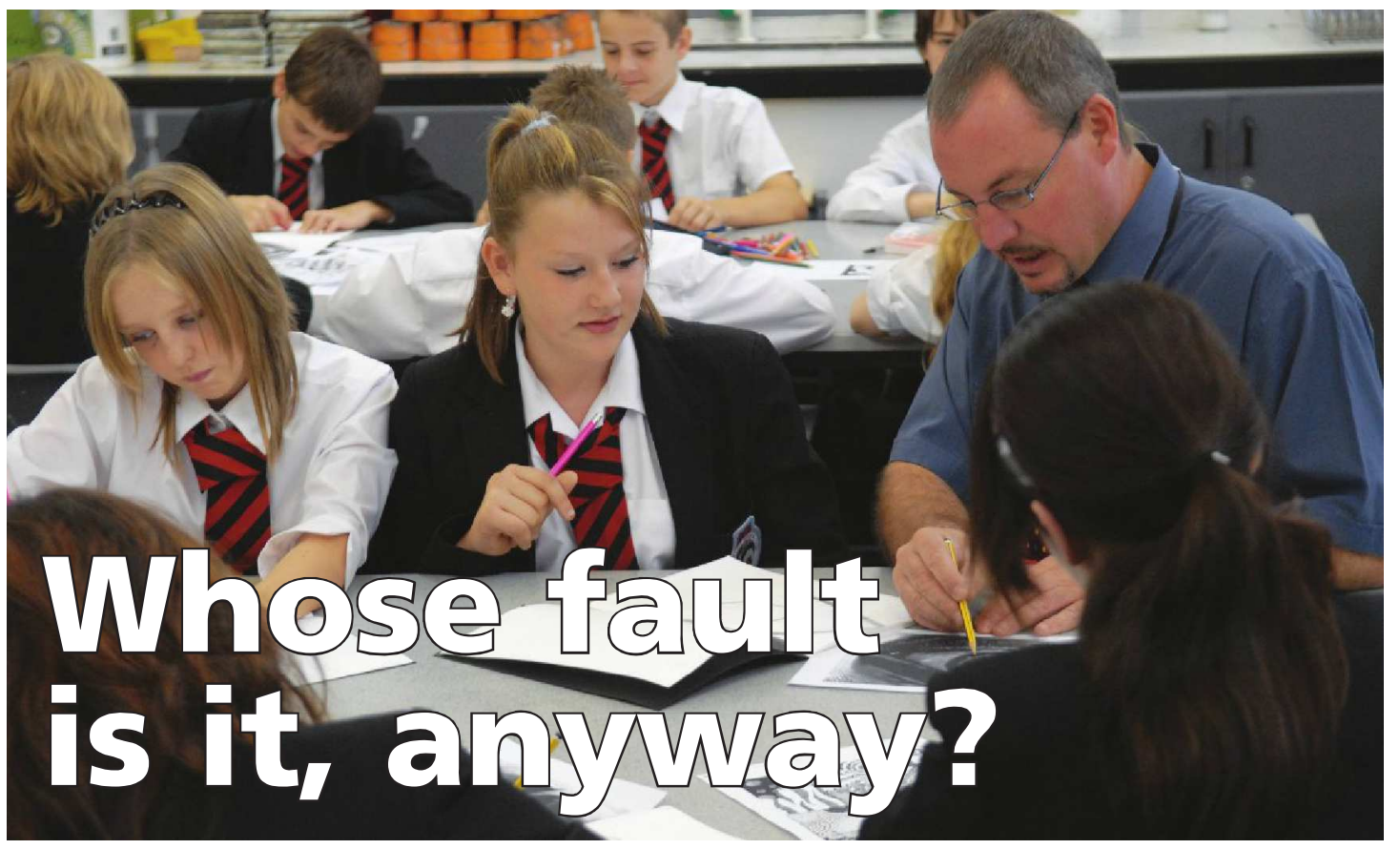

Is a teenager's academic success really down to the school and its teachers or are wider factors at play? Psychologist Dr Stephanie Thornton discusses

\section{Moral support: National Children's Bureau}

\section{Learning about HIV}

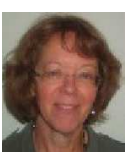

Thousands of children are affected by HIV

and schools have a crucial supporting role to play. Dr Hilary Emery explains

THERE ARE around 1,200 children and youn people in the UK and Ireland who were infected with HIV during birth or infancy, and more young people acquiring HIV through unprotected sex.

A conservative estimate is that 20,000 children and young people are affected by the presence of HIV in their families, many of whom are at secondary
school. The number of people with HIV in the UK has trebled in the last decade to 91,500, and a quarter of those infected are undiagnosed. Despite this, las Children's Bureau - found that a quarter of youn people had not learnt about it at school.

The role of secondary schools in supportin young people who are living with, affected by, or at the delivery of sex and relationships education (SRE) the delivery of sex and relationships education (SRI
and the way teachers and pupils talk about HIV.

Due to stigma, many children living with or affected by HIV are unaware that the conditio or care for a family member. Many become aware it or care for a family member. Many become
is HIV around the start of secondary school.

During their school career, they will need grapple with decisions about telling others. If they are themselves HIV positive, they'll need to get transmissible infection, the "reckless transmission" of which is criminalised. They will need to understan he implications for their own lives and relationships. HIV is often a family condition and frequently occurring experiences are silence and secrecy at home mental health difficulties, caring responsibilities, an HIV-related discrimination against school pupils occurs the world over. In 2010, the UK's Children's
HIV Association struggled to find a school that would HIV Association struggled to find a school that would
hire out its facilities for a summer camp for HIV- positive young people. HIV professionals hear how some teachers reflect the contradiction that exist around HIV, namely that HIV can be seen as both a
late 20th century problem that has fallen off the radar and an immediate menace, presented as far more contagious than it actually is.

We've heard about families who have had to relocate after their HIV information leaked from the school into the community, and even of one teacher who told a class that if diagnosed with HIV, he would kill himself. The saddest aspect of these stories is that young people, silenced by stigma, feel unable to challenge it.

The impact of a positive reaction to the disclosure of HIV by a young person or parent cannot be underestimated. Most people restrict knowledge of their diagnosis beyond a small circle of HIV professionals. So, an empathetic response from teachers shows students and parents that they can have the confidence in themselves and trust in others. To young people affected by HIV, effective if a pupil is affect In most cases, schools won't know cases of HIV transmission in a school environmen

mo obligation to inform a school, and if young person is well - as many are - often no reason for the school to know. However, young people should feel able to disclose their diagnosis and acces any support they need.

One key way to make schools "HIV-friendly" is to mainstream HIV into school policies around health, inclusion, SRE and confidentiality, mentioning alongside other characteristics and conditions.

In terms of teaching, HIV offers an important learning opportunity as well as being an essential component of comprehensive SRE. Its story feature some of the greatest scientific achievements, most inspiring global citizens and most contentious debates of our age. Understanding HIV teaches us all to bc more humane, pragmatic and non-judgemental qualities that are valuable through life for everyone.

- Dr Hilary Emery is chief executive of the National Children's Bureau, which works in partnership wit Further information

For more information about supporting students with HIV or teaching about HIV, visit the HIV Network'
pages on the NCB website: www.ncb.org.uk/hiv education and support means recognising that people wive HIV are among us, similar to us, and striving to

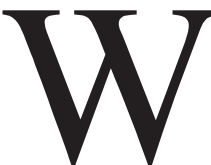

all know that the quality teacher not only imparts information, but conveys an infectious enthusiasm for the
subject and for learning in general. A bad teacher can confuse and demoti general. A bad teacher can
killing the most intriguing of subjects stone dead.

And we all know that the quality of leadership matters, too. A head who is in command, who creates positive dynamic in which the cflots of students and teachers - are recognised and appreciated, who individual in the school, creates an environment that empowers. An ineffectual head who can inspire neither staff nor students allows negative
take command, and results to fall.

So let's agree: the quality of teaching and the quality
Sommand, and results to fall. So let's agree: the quality of teaching and the quality
of leadership in a school really do matter. High quality of leadership in a school really do matter. High quality in these areas is beyond doubt a necessary condition for to guarantee a school's success, as some want to claim?
This is an issue that needs to be explored urgently This is an issue that needs to be explored urgently in a time when the powers that be are inclined to
evaluate schools and their staff primarily in light of evaluate schools and their staff primarily in light of the achievements of their students. Is that rational? Productive? Or is it

in passing the buck?
Without doubt, there are some people in teachin than good. And without doubt, there are so

Let the authorities beat the schools for failure if they want to. But don't let's expect that to fix anything. The truth is that the education cannot succeed unless the young invest in it.

And society at the moment offers them precious little reason to do that

creativity and who offer gloom rather than inspiration. Replacing these with other, more able individuals is very likely to produce

But even in these cases, will it last? There is phenomenon, well known to psychology, called the Hawthorne effect: any change (however irrelevant) produces a surge in performance for a while, just because it is a change, and after a while, after the cameras move on, everything reverts to what it was

The fact is that no-one embarks on a teaching career Oncentending to fail.

One can be sure of this, not because one has a strong belief in the goodness of human nature but because
teaching is so arduous and so poorly paid: the cynical employed elsewherc.

The odd individual is wrongly placed, and perhaps better pruned. But if a whole school culture has set by the attitudes of their peer culture. schools more than others. effect on school attainment. family breakdown or economic trauma.

We mist be second rate, to "go through the motions", to not are. No-one accepts all the stresses and strains of teaching is so arduous and so poorly paid: the cynical
and exploitative could be so much more profitably

are circumstances that would try the patience, the the best of staff. The fact is that some catchment areas simply do not There are factors that affect educational success that lie far outside the gates - and control - of the school. There is the obvious: given that all human abilitie are "nomally distributed", we all know that by that bell-s half the population will fall below the top of bell-shaped curve, and some will fall quite a way And we know full well that there are systematic differences between catchment areas that mean that this will impact differently on different schools. Given exactly the same quality of teaching input,
schools will do better than others as a result. Can such problems be rectified at the school level? In principle, yes: given sufficient resources, and other things being equal, it is entirely feasible to provide the individualised input that every student needs to reach in schools, I have ns. But in 30 years of research resources to properly assess, let alone address, the individual needs of all its weaker students. And other ings have never been equal. seographical, social, cultural and political. And things, those influences that lie far beyond the attainment of its pupils.

In inner city America, Black American high school students systematically fail. They fall short of the poorly aspirations for them. Is it genetic? No. Are they fine for other $\mathrm{Nem}$ - the schools in which they "fail" are problem is elsewhere. It seems that the edugsts that aspirations (or not) of inner city Black Americans are

作 th. That will alienate you from your peer group, which can have dangerous - maybe even fatal - consequences. Cest? That is in some UK commuitics, belonging mates And like, education - and such effects systematically hit some

And then, family stress, social or economic (which tend to fuse, one leading to the other) also has a huge

The best evidence comes from Terman's study of children would decline, failing to most gifted standards and even scoring lower on IQ tests, after a

Such effects are sometimes individual, hitting one family in a community where most thrive. But in our suffering from unemployment and the stresses which that engenders (and again, the effects are starker in seriously. They are not stupid. And the way the world and you will succeed" as a new version of "the old lie". lh Greece, even professionals have lost income, pension, prospects. Their education does not protect them. Why study, if that is the truth? Their offspring
have reacted accordingly: attainment is crashing in
Greek schools. Even in UK,

describe thems.

Today, a huge percentage of recent UK graduates are shelf-stacking in supermarkets or in similarly menial jobs. Around 20 per cent have no job at all. Few have real prospects, and all have huge debts. Many school-leavers find themselves unemployed, however well qualified.

Educational achievement today is not the ticket example, now $£ 40,000$-plus in debt and with zero inged, it is hard to fishing. want to. But don't let's expect that to fix anything. The young invest in it. And society at the moment offers them precious little reason to do that. And the remedy for that is far beyond the school gates.

Dr Stephanie Thornton is a chartered psychologist and arstephanie Thomton is a chantered psychologist and truth is that the education cannot succeed unless the 


\section{Stretching their horizons}

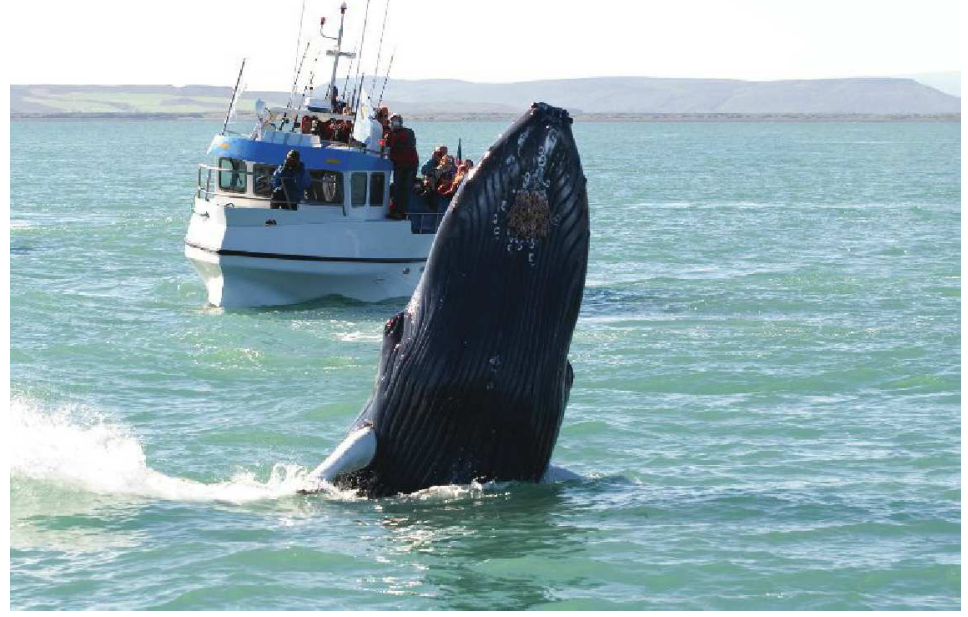

Nick Parks, an international ski and mountain guide and former head of outdoor education at Marlborough College, discusses how travel can be used across the curriculum and the work of the Stretching Horizons network

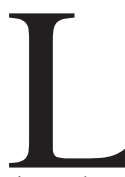

ater this year, teachers and adventurers travel, legal and safety experts will
congregate at the annual Stretching congregate at the annual Stretching Horizons' conference, to discuss some of the ways schools can enrich education, mitigate risk and raise
funds for educational journeys with

view to changing lives. have a transformational effect on students. Education ravel is something that many people feel passionate about and in a time of increasing globalisation, worldexperience can have a valuable and lasting impact on young people.

Whether the journey is a sightseeing break fo historical or geographical context, a sports tour to promote friendly competition and teamwork with overseas schools, or helping communities in developing nations, the experiences often continue to shap students' world-views long after their return home. The Stretching Horizons overseas educational trave network is underpinned with a desire to celebrate an Adrian Ferraro, explained: "Potential is a powerful thing and allowing students to experience life beyond the boundaries of the classroom, the school or the local community is an incredibly useful tool to help them discover their potential.

"I speak to teachers every day who have amazing stories to tell, from the inspirational to the humorous, eye-opening to eye-watering; but all stories seem to hout them would ever be possible in the classroom.

"We wanted to bring people together to help teachers create a toolkit for educational travel, from ideas fo inspiring journeys for the best educational outcomes through to practical advice regarding logistics, health and safety and funding."

Running alongside the conference, the Stretchin Horizons' Educational Journey of the Year Award was created to celebrate some of the amazing journeys taken by schools throughout the UK.

The winning school will be awarded with a six-day trip to Morocco for eight teachers, which includes visit to Marrakech, a camel safari, a night in the
desert, a trip to the UNESCO site of Ait Benhaddou, and a day in the life of a Berber experience in the

Graham Derrick, a trustee from national charity Youth Explorer's Trust, is one of the judges: "Th benefits of educational travel are incredibly far-reaching and are almost impossible to quantify. Any adult who has taken a group of young people on an overseas educational journey takes on an awesome responsibility, not only for the day-to-day survival of the young members, but, ultimately, for decisions which they might make in years to come. A celebration of these individuals, teachers and students alike, is something I'm incredibly pleased to be a part of "

One of National Geographic's Adventurers of the Year, author Alastair Humphreys, is well-versed in giving talks to teachers and students about his experiences. As a speaker at the conference this year, his aim is to inspire "I began enjoying learning when I began wandering the world," he explained. "No longer was I learning stuff simply to regurgitate it in hot exam halls. School on the road is different: the more you know the more you want to know. It is important for pupils to learn about challenge, risk, geography, citizenship, history, cultural awareness, moral and social issues and much more without feeling as though they are learning."

Another theme integral to Stretching Horizons enabling teachers to learn from each other and form vital collaborative links, b internationally. Paul Miller, a teacher at Ashton Park on expeditions during his career, and has been working with the Maji Safi charity and Inspirations School since 2003 to help transform education for a

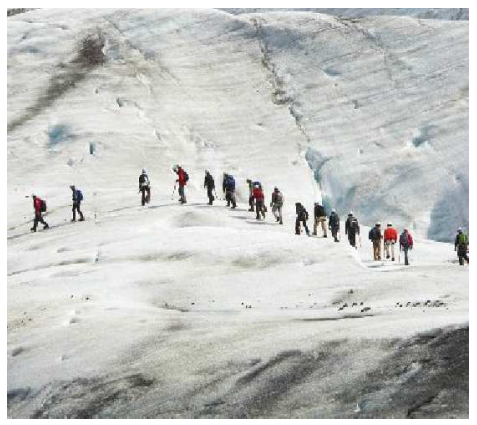

He said: "The aim behind all of our trips has been to help build an effective learning environment for local Kenyan pupils, so the experiences that this gives our students are in actual fact a really welcome side-effect. "The skills that this project gives to our students are far-reaching and not just linked to the curriculum; they have helped to build eight classrooms, teachers offices, playgrounds and special rooms for disabled students, which have been key to building skills such as amwork, collaboration, time-management."

The more abstract lessons are no less important, Mr Miller explained: "Empathy grows out of their understanding of the challenges that this community faces, and puts a lot of issues into context in a way that would just not be possible inside the classroom. It also makes them incredibly proud, which is just fantastic Fundraising makes the journey a cost-effective educational tool for the students, and has the added benefit of extending the learning benefits beyond the dates of the trip. Mr Miller continued: "I've had students who have lobbied local businesses, or who
have built their commerce skills by selling at school have built their commerce skills by selling at school events. It's not about getting mum and dad or the school
to pay. In most cases, we've worked together with School in Bristol, has taken more than 200 students students to raise funds for their trip and the involvement of the local community brings a sense of togetherness
to the experience. It's this sort of thing, as well as the to the experience. It's this sort of thing, as well as the
actual journey, which helps make a student's world actual journey, which helps make a student's world grow right before their eyes." Supporting schools in planning and logistics is
another important focus, and it is vital that schools are another important focus, and it is vital that schools are well-prepared for all aspects of their journey, explained
Julian Penney, a risk and travel expert and director of Pharos Safety.

\section{I speak to teachers every day who have amazing} stories to tell, from the inspirational to the humorous, eye-opening to eye-watering; but all stories seem to have a common thread - travel teaches pupils more about themselves and about the world around them than would ever be possible in the classroom

He continued. "It really is crucial that schools are students to begin with to more than 500 , and by the time upported in making sure that the risks are managed the project is finished there will be 800 students. It's and balanced by the benefits of the trip. Well-managed now the third highest performing school in the area." ask is a really positive lesson; exposure to a certain - an integral part of the Bristol-Kenya link for the 2012 Legal experts also help schools walk the Olympic Games: 'I don't even think I knew how farreaching the effects of these trips would be, not just to "Logistics are the dry-but-necessary part of any trip" local community" he added.

Mr Penney continued. "Planning is the key; not "For every story I have to tell, there must be "Tor every story I have to tell, there must be mergency situations and step-by-step guides that are gathering together to share them."

articular to the region that the group is testling in

- Nick Parks is an international ski and mountain

Ultimately, Mr Ferraro explained, the network,

Mulde former head of outdoon education at founders of the Strething Horizons netwe of country. "Whether trips are geography, history or

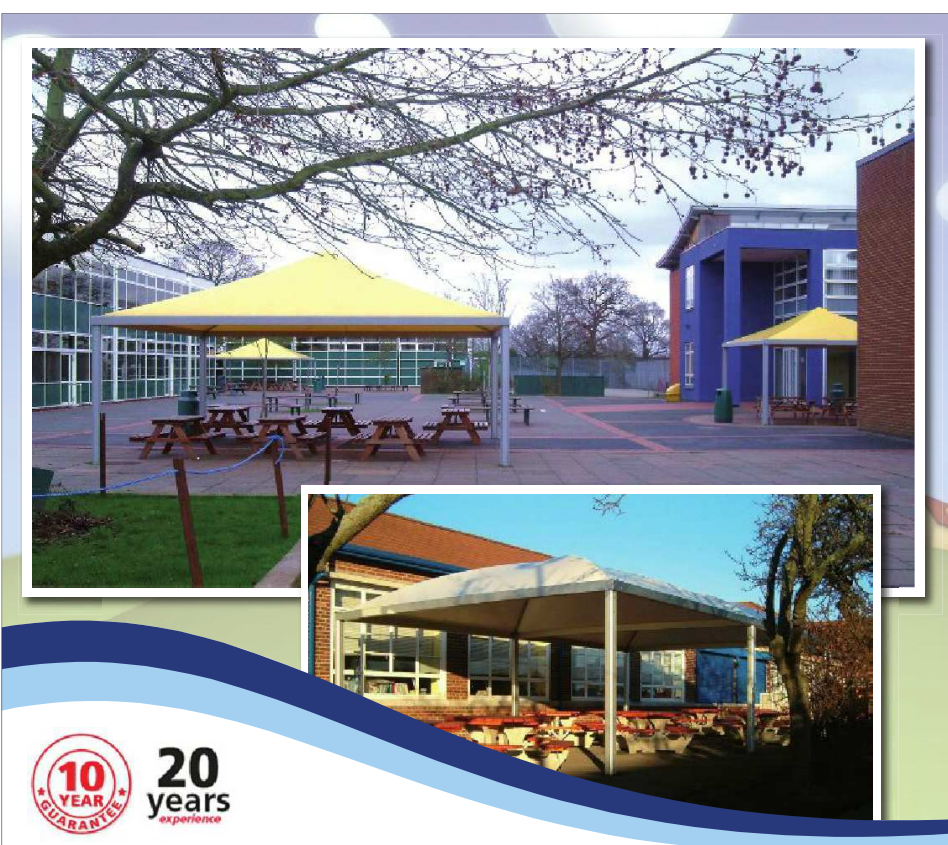

Outdoor covered areas - An ideal solution to your learning, dining and social space needs getting the fresh air that they need at the same time as being protected from harmful UVA and UVB rays, or even from the rain!

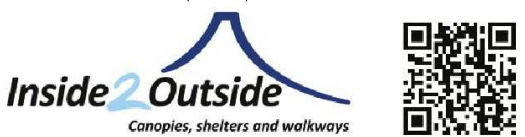

